MARIA FERNANDA REBELLO HORTA 

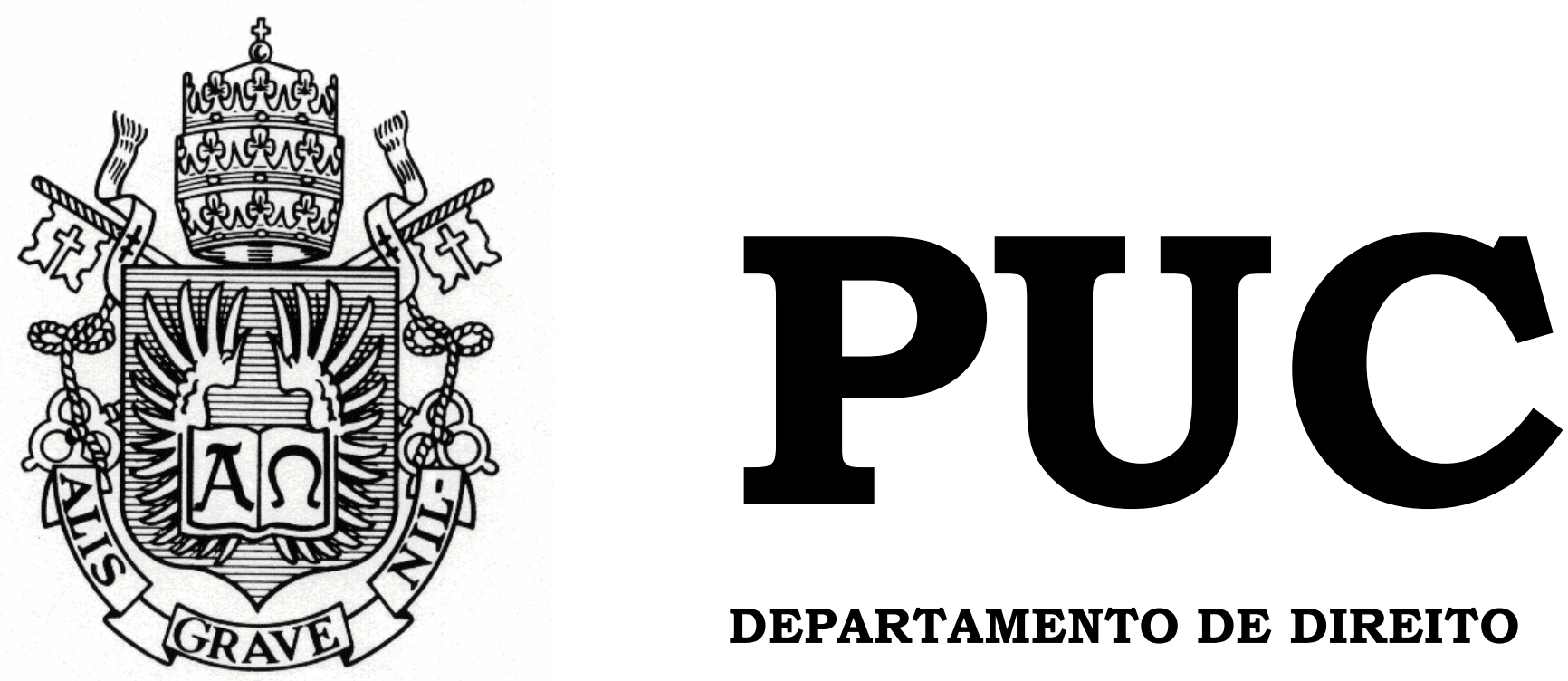

DEPARTAMENTO DE DIREITO

\title{
REPRODUÇÃO HUMANA ASSISTIDA POST MORTEM E SEUS EFEITOS NO DIREITO SUCESSÓRIO
}

\author{
por \\ MARIA FERNANDA REBELLO HORTA
}

ORIENTADOR: MARCUS DANTAS

2008.2

PONTIFÍCIA UNIVERSIDADE CATÓLICA DO RIO DE JANEIRO

RUA MARQUÊS DE SÃO VICENTE, 225 - CEP 22453-900

RIO DE JANEIRO - BRASIL 


\title{
Reprodução humana Assistida Post MORTEM E SEUS EFEITOS NO DIREITO SUCESSÓRIO
}

\author{
por \\ MARIA FERNANDA REBELLO HORTA
}

\begin{abstract}
Monografia apresentada ao
Departamento de Direito da

Pontificia Universidade Católica do

Rio de Janeiro (PUC-Rio) como requisito parcial para a obtenção do Título de Bacharel em Direito.
\end{abstract}

Orientador: Marcus Dantas 
Aos meus pais Telma e Luiz Guilherme.

À minha irmã Juliana.

Ao meu namorado Pedro. 


\section{AgRADECIMENTOS}

Do fundo do meu coração, agradeço aos meus pais, Telma e Luiz Guilherme, pela educação, Amor e incentivo de sempre. À minha irmã Juliana por todo o Amor, apoio e amizade. Ao meu namorado Pedro pelo Amor, estímulo e companheirismo.

Agradeço ao professor orientador Marcus Dantas e à professora e coorientadora, Kátia Regina da Costa Silva Ciotola, pelo incentivo e pela ajuda essenciais à produção desta monografia.

À amiga Tatiana Castiglione, pela paciência.

Aos funcionários do Núcleo de Prática Jurídica, em especial Luciana Queirós, Leopoldo Pereira e Eduardo Domingos, que sempre estiveram ao meu lado e me ajudando nesses últimos dois anos.

Aos meus colegas e professores da PUC-Rio.

Aos funcionários do departamento.

A todos os amigos e familiares que de uma forma ou de outra me estimularam e me ajudaram. 
"A minha fé mais profunda é que podemos mudar o mundo pela verdade e pelo amor." 


\section{Resumo}

No mundo em que vivemos, são gigantescos os avanços da ciência em matéria de reprodução humana. E, diante do avanço tecnológico das técnicas de reprodução humana assistida, torna-se impreterível a produção e edição de uma legislação, que discipline a utilização dessas técnicas, uma vez que o controle hoje é basicamente feito de maneira informal, por meio de valores éticos e morais. Nesse aspecto, esse é um tema no qual o Direito ainda engatinha.

Até os dias atuais não há no Brasil regulamentação e, sequer, jurisprudência acerca do direito sucessório nos casos de concepção post mortem e da implantação de embriões congelados após a morte do genitor. Não há nem mesmo notícia da ocorrência dessas situações em nosso país, muito em função da falta de controle por parte do Estado, no que diz respeito à reprodução humana assistida.

Nesse contexto, imperioso ressaltar que o presente trabalho tem a finalidade de, com base na recente doutrina e em casos estrangeiros, analisar as hipóteses que já temos conhecimento acerca da reprodução humana assistida envolvendo o direito sucessório, em especial as situações em que a inseminação artificial e a implantação embrionária são feitas após a morte do genitor. Assim sendo, é de extrema importância discutir os direitos e deveres envolvidos nessas relações, principalmente com relação à criança gerada por meio dessas formas de tratamento de reprodução humana assistida. 


\section{Palavras-Chave}

Reprodução humana assistida post mortem, direito sucessório, biodireito, princípio da dignidade da pessoa humana, princípio do melhor interesse da criança, filiação. 


\section{SUMÁRIO}

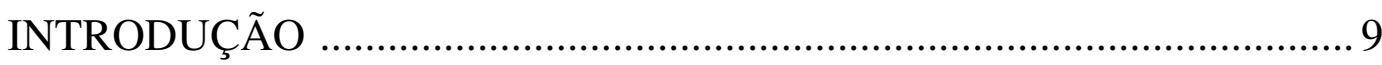

\section{CAPÍTULO I - HISTÓRICO}

1.1 - A evolução do direito das famílias e do direito sucessório ...... 14

1.2 - O surgimento do biodireito como um novo ramo jurídico ....... 19

CAPÍTULO II - AS TÉCNICAS DE REPRODUÇÃO HUMANA ASSISTIDA (RHA)

2.1 - Considerações iniciais ................................................................ 23

2.2 - Evolução histórica das técnicas de reprodução assistida..........24

2.3 - As técnicas de reprodução humana assistida..............................25

2.3.1 - Inseminação Intra-uterina (IIU) .................................. 26

2.3.2 - Transferência Intrafalopiana de Gametas (GIFT) ..... 27

2.3.3 - Fertilização In Vitro (FIVETE) …………………….... 27

2.3.4 - Transferência Intrafalopiana de Zigoto (ZIFT) ......... 28

2.4 - Considerações acerca do material reprodutivo........................... 28

\section{CAPÍTULO III - A VOCAÇÃO HEREDITÁRIA E A INTERPRETAÇÃO}

DOS ARTIGOS 1.798 E 1.799 DO CÓDIGO CIVIL

3.1 - Breve introdução ao direito das sucessões .................................. 34

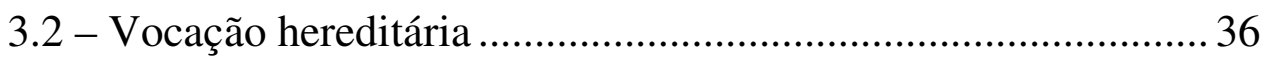

3.3 - A diferença entre reprodução humana assistida post mortem e a implantação de embriões congelados post mortem e os efeitos destas na vocação hereditária 


\section{CAPÍTULO IV - PRINCÍPIOS CONSTITUCIONAIS}

4.1 - Princípio da dignidade da pessoa humana ................................. 47

4.2 - Direito à filiação e o melhor interesse da criança...................... 51

4.3 - Princípio da igualdade entre os filhos .......................................56

CAPÍTULO V - PRESUNÇÃO DA PATERNIDADE NA REPRODUÇÃO ASSISTIDA HOMÓLOGA, AINDA QUE MORTO O GENITOR

5.1 - Considerações acerca da filiação ................................................ 60

5.2 - Aplicação da regra do artigo 1.597, incisos III e IV, do Código Civil, à concepção e à implantação embrionária póstumas 61

CAPÍTULO VI - OS EFEITOS DA CONCEPÇÃO E DA IMPLANTAÇÃO DE EMBRIÕES CONGELADOS APÓS A MORTE DO GENITOR NOS DIREITOS DE FAMÍLIA E DAS SUCESSÕES

6.1 - Uma solução a favor da criança. 67

6.2 - A questão do prazo para a utilização do material genético

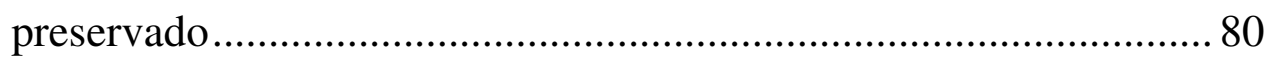

6.3 - Projetos de lei sobre reprodução assistida .................................. 81

CONCLUSÃO

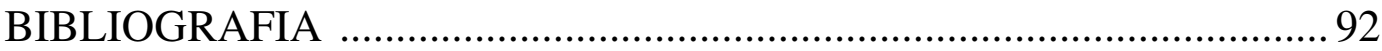

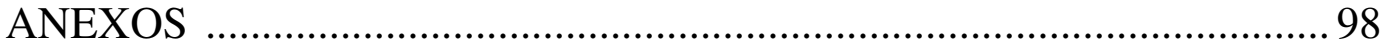




\section{INTRODUÇÃO}

O problema da esterilidade humana fez com que vários avanços científicos fossem desenvolvidos. Contudo, esse grande desenvolvimento tecnológico no campo da reprodução humana assistida trouxe consigo as reflexões e as discussões sobre a importância de haver normas jurídicas que orientassem estas questões.

De fato, as técnicas de reprodução humana artificial têm como finalidade pôr à disposição do ser humano um meio de solucionar problemas de infertilidade. No entanto, diante das diversas relações de direito conseqüentes desses procedimentos, os conflitos gerados diante da falta de legislação específica para disciplinar as condutas são enormes.

Para a solução desses conflitos não basta a orientação do art. $4^{\circ}$ da Lei de Introdução ao Código Civil: "Quando a lei for omissa, o juiz decidirá de acordo com a analogia, os costumes e os princípios gerais de direito”. Também a doutrina e a jurisprudência não oferecem solução para os problemas que podem ocorrer, uma vez que são escassas acerca da matéria, pois envolvem o bem supremo da humanidade que é a vida. ${ }^{1}$

Basta nos depararmos com a possibilidade de utilização de técnicas de reprodução humana assistida em que embriões são congelados e nem todos são utilizados. Ou também com a possibilidade de congelamento de material genético (oócitos e gametas) por anos.

Tais situações fazem surgir questionamentos não exclusivamente sobre o destino desse material genético, mas também sobre as seqüelas no direito sucessório quando a implantação ocorre depois do falecimento de

\footnotetext{
${ }^{1}$ FERNANDES, Silvia da Cunha. As Técnicas de Reprodução Humana Assistida e a Necessidade de sua Regulamentação Jurídica. Rio de Janeiro: Renovar, 2005. p. 3.
} 
quem fez uso de tais técnicas reprodutivas ou quando a própria técnica reprodutiva é realizada postumamente. ${ }^{2}$

Estes questionamentos serão analisados ao longo deste trabalho que em um primeiro momento irá expor os fatos históricos, tanto da instituição família como do direito sucessório. Será exposto o desenvolvimento da biotecnologia e do biodireito e o surgimento das técnicas de reprodução humana assistida (RHA).

Em um segundo momento, trataremos especificamente das técnicas reprodutivas, no que diz respeito aos procedimentos existentes e suas conseqüências no mundo do direito.

Posteriormente, entraremos na discussão acerca da vocação hereditária, analisando o artigo 1.798 do Código Civil, que determina quais pessoas estão legitimadas a suceder. Além disso, trataremos da importante distinção entre dois procedimentos específicos, quais sejam, o da concepção homóloga post mortem e o da implantação embrionária post mortem.

Cabe desde já esclarecer, que são procedimentos distintos, tanto para o direito, quanto para a própria medicina, uma vez que no primeiro a concepção é realizada após a morte do genitor, enquanto que no segundo a concepção acontece in vitro, antes da morte do genitor.

Após, serão analisados os princípios constitucionais pilares da reprodução assistida e do direito sucessório, ou sejam, os princípios da dignidade da pessoa humana, da igualdade entre os filhos, do direito à filiação e do melhor interesse da criança, assim como os efeitos de tais princípios. Em seguida, falaremos da presunção de paternidade nos casos de reprodução humana assistida, considerando o que determina o artigo 1.597, incisos III e IV, do Código Civil.

Por fim, analisaremos os efeitos da concepção e da implantação embrionária póstumas no direito de família e no direito das sucessões, além

\footnotetext{
${ }^{2}$ Ibid. p. 4.
} 
de destacarmos uma série de projetos de lei que objetivam regulamentar essas questões tão polêmicas.

O objetivo deste trabalho, portanto, é trazer à discussão a polêmica e interessante situação acerca da possibilidade de reprodução humana póstuma. O mundo científico evoluiu de tal maneira que o direito não conseguiu acompanhar e nossa intenção é, desta forma, trazer à tona esses questionamentos e dúvidas, sem o intuito e a pretensão de prever uma solução perfeita, mas tão-somente uma solução condizente com os dias atuais.

Todos os casos a serem analisados envolvem questões muito delicadas e sentimentos profundos que não podem ser analisados somente sob o ponto de vista jurídico. Contudo, não é o objetivo deste trabalho analisar questões éticas, religiosas, de comportamento, psicológicas, etc. O objetivo principal da presente monografia é analisar os efeitos jurídicos acerca da concepção artificial e da implantação de embriões após a morte do genitor.

Ao longo desta análise, vamos nos defrontar com diversos questionamentos envolvendo os direitos do genitor, da mãe e, principalmente, da criança, fruto da possível concepção ou implantação post mortem.

O que podemos esclarecer desde já é que a estrutura das disciplinas jurídicas é passível de modificações que ocorrem em função das mudanças ocorridas na própria vida humana. Quando acontece uma experiência nova na vida humana, na sociedade ou na área técnica ou científica, é bem provável que esta mudança repercuta no próprio direito.

Esta correspondência entre a experiência social e a prática jurídica é muito comum, mas ainda assim pode acontecer de nos sentirmos chocados, em certos momentos, por descobrirmos que o direito não está prevenido o bastante para solucionar certos problemas inovadores e bem por isso, 
deverá ser o próprio direito que terá que mudar, para que aquele problema não reste sem solução. ${ }^{3}$

Há certas inovações humanas que, mesmo sendo inevitáveis, não podem ser solucionadas pelos mecanismos jurídicos disponíveis no momento de seu surgimento. A expressão biodireito é o resultado mais claro de nossa dificuldade em lidar com as inovações humanas. Pela expressão biodireito tentamos silenciar um conjunto de perplexidades que talvez ainda não sejam plenamente compreensíveis por nós. Por biodireito tem sido entendido o que seria um novo ramo do direito que busca apreciar juridicamente as novas práticas humanas de manipulação da vida. ${ }^{4}$

Mas e o que acontece quando se tenta fazer um cotejo entre o biodireito e o direito das sucessões?

Pode até parecer uma relação fácil de ser feita, contudo, o que se vê é que nosso direito sucessório (Código Civil de 2002) pertence a um mundo diferente deste em que a tecnologia genética pode, entre tantas outras coisas, viabilizar uma concepção de uma criança mesmo após a morte dos seus ascendentes biológicos.

O nosso direito sucessório não se expressa com atualidade e segurança, a respeito de temas relacionados com as novas biotecnologias, como no caso da definição da condição sucessória do embrião préimplantatório, ou ainda, no caso da concepção post mortem. ${ }^{5}$

Portanto, o que se passa na verdade é que o legislador brasileiro não consegue acompanhar a realidade social nem perceber as inquietações da família de hoje em dia. A sociedade evolui, transforma-se, rompe com

\footnotetext{
${ }^{3}$ HIRONAKA, Giselda Maria Fernandes Novaes. As inovações biotecnológicas e o direito das sucessões. Disponível em <http://www.ibdfam.org.br>. Acesso em 10 de jul. 2008.

${ }^{4}$ Em Wikipédia, a enciclopédia livre, encontra-se o seguinte verbete: "Biodireito é o ramo do DIREITO PÚBLICO que se associa à BIOÉTICA, estudando as relações jurídicas entre o DIREITO e os avanços tecnológicos conectados à MEDICINA e à BIOTECNOLOGIA."

${ }^{5}$ HIRONAKA, Giselda Maria Fernandes Novaes. As inovações biotecnológicas e o direito das sucessões. Disponível em <http://www.ibdfam.org.br>. Acesso em 10 de jul. 2008.
} 
tradições e o que deveria acontecer, mas não acontece, seria a constante atualização das leis.

Contudo, a tendência hoje em dia é simplesmente fazer a atualização normativa, sem dar atenção para o espírito das diversas mudanças ocorridas no meio social, "o que fortalece a manutenção da conduta de apego à tradição legalista, moralista e opressora da lei”. 6

O desenvolvimento da chamada globalização faz com que ocorra a constante modificação de regras, leis e comportamentos. Entretanto, a mais difícil e complexa tarefa é mudar as regras do direito das famílias e das sucessões.

A autora Maria Berenice Dias leciona o seguinte:

"Quando se trata das relações afetivas, a missão é muito mais delicada em face de seus reflexos comportamentais que interferem na própria estrutura da sociedade. O regramento jurídico da família não pode insistir, em perniciosa teimosia, no obsessivo ignorar das profundas modificações culturais e científicas, petrificado, mumificado e cristalizado em um mundo irreal, ou sofrerá do mal da ineficácia." 7

\footnotetext{
${ }^{6}$ DIAS, Maria Berenice. Manual de Direito das Famílias. $4^{\text {a }}$ Ed. São Paulo: Revista dos Tribunais, 2007. p. 95.

${ }^{7}$ Ibid.
} 


\section{Capítulo I}

\section{Histórico}

\subsection{A evolução do Direito das Famílias e do Direito Sucessório}

A instituição chamada família sofreu extremas mudanças ao longo dos últimos séculos. E apesar das atualizações legislativas ocorridas desde então, nem mesmo a Constituição Federal conseguiu acompanhar tantas mudanças. Apesar de hoje haver muitos tipos de famílias, a Lei Maior não as reconhece todas como tais.

O declínio do patriarcalismo, a globalização e a inclusão da mulher no mundo do trabalho, em conjunto com a evolução do conhecimento científico, geraram uma grande transformação da família, principalmente a partir da segunda metade do século passado. Com isso, os parâmetros estruturadores da organização jurídica sobre a família, o sexo, o casamento e a reprodução desatrelaram-se. Não é mais essencial e necessário o sexo para haver a reprodução humana e o casamento não é mais a única maneira de se legitimar as relações sexuais. ${ }^{8}$

A caminhada da família rumo adentro desse novo milênio está sendo feita com concepções e valores morais e sociais completamente diferentes dos da primeira metade do século XX. A grande mudança da família é que ela deixou de ser apenas um núcleo econômico e de reprodução para ser o espaço do companheirismo, do amor e do afeto. ${ }^{9}$

Apesar de todas essas mudanças, a família continua sendo o primeiro agente socializador do ser humano, ou seja, é o primeiro balizador social de qualquer criança. Mas há muito tempo deixou de ser uma extensão do

\footnotetext{
${ }^{8}$ PEREIRA. Rodrigo da Cunha. Apresentação ao II Congresso Brasileiro de Direito de Família. In: Anais do II Congresso Brasileiro de Direito de Família. Disponível em <www.ibdfam.com.br>. Acesso em 15 jun. 2008.

${ }^{9}$ Ibid.
} 
Estado, e hoje é vista como uma parte da sociedade. A família é tida como base da sociedade (uma vez que é a primeira instituição socializadora da pessoa) e, por esta razão, recebeu especial atenção do Estado.

O artigo 226 da Constituição Federal e seus parágrafos 10 estabelecem a forma de constituição da família. A Lei Maior estabelece que a família é base da sociedade e, em seu parágrafo $7^{\circ}$, determina que o planejamento familiar é livre decisão do casal, fundado nos princípios da dignidade da pessoa humana e da paternidade responsável, competindo ao Estado propiciar recursos educacionais e científicos para o exercício desse direito.

A família é tanto uma estrutura pública como uma relação privada, pois identifica e explicita o indivíduo como integrante do vínculo familiar e também como participante do contexto social. O formato hierárquico da família cedeu lugar à sua democratização, e hoje as relações são muito mais de igualdade e de respeito mútuo. ${ }^{11}$

O Código Civil de 1916 regulava a família existente no início do século passado, constituída única e exclusivamente pelo matrimônio. Em sua versão original, o Código de 1916 trazia uma oblíqua e discriminatória visão da família, limitando-a ao grupo que se origina no casamento. As

\footnotetext{
${ }^{10}$ Art. 226. A família, base da sociedade, tem especial proteção do Estado.

$\S 1^{\circ}$ - O casamento é civil e gratuita a celebração.

$\S 2^{\circ}$ - O casamento religioso tem efeito civil, nos termos da lei.

$\S 3^{\circ}$ - Para efeito da proteção do Estado, é reconhecida a união estável entre o homem e a mulher como entidade familiar, devendo a lei facilitar sua conversão em casamento.

$\S 4^{\circ}$ - Entende-se, também, como entidade familiar a comunidade formada por qualquer dos pais e seus descendentes.

$\S 5^{\circ}$ - Os direitos e deveres referentes à sociedade conjugal são exercidos igualmente pelo homem e pela mulher.

$\S 6^{\circ}$ - O casamento civil pode ser dissolvido pelo divórcio, após prévia separação judicial por mais de um ano nos casos expressos em lei, ou comprovada separação de fato por mais de dois anos.

$\S 7^{\circ}$ - Fundado nos princípios da dignidade da pessoa humana e da paternidade responsável, o planejamento familiar é livre decisão do casal, competindo ao Estado propiciar recursos educacionais e científicos para o exercício desse direito, vedada qualquer forma coercitiva por parte de instituições oficiais ou privadas.

$\S 8^{\circ}$ - O Estado assegurará a assistência à família na pessoa de cada um dos que a integram, criando mecanismos para coibir a violência no âmbito de suas relações.

${ }^{11}$ DIAS, Maria Berenice. Manual de Direito das Famílias. $4^{a}$ Ed. São Paulo: Revista dos Tribunais, 2007. p. 28.
} 
referências feitas pelo código velho aos vínculos tidos fora do casamento eram punitivas e serviam exclusivamente para excluir direitos (a exemplo de denominações discriminatórias como o concubinato e os filhos ilegítimos).

A evolução pela qual passou a estrutura das famílias acabou forçando sucessivas alterações legislativas.

A Constituição Federal de 1988 ultrapassou séculos de hipocrisia e preconceito. Determinou a igualdade entre o homem e a mulher e alargou o conceito de família, passando a proteger de forma igual todos os seus membros. Estendeu igual proteção à família constituída pelo casamento, bem como à união estável entre o homem e a mulher e à comunidade formada por qualquer dos pais e seus descendentes, que recebeu o nome de família monoparental. Consagrou a igualdade entre os filhos, havidos ou não dentro do casamento, ou por adoção, garantindo-lhes os mesmos direitos e qualificações. Essas enormes modificações acabaram derrogando diversos dispositivos da legislação então em vigor, por não terem sido recepcionados pela nova Constituição Federal. E, desta forma, o Código Civil perdeu o papel de lei fundamental do direito de família. ${ }^{12}$

O atual Código Civil entrou em vigor em 11 de janeiro de 2003 e procurou atualizar os aspectos essenciais do direito de família adequando-os à Lei Maior, mas não deu passos mais ousados, nem mesmo em temas constitucionalmente consagrados. Isso porque o Código já nasceu velho, uma vez que foi elaborado ao longo de todo o século XX e, portanto, não foi completamente bem sucedido e ainda sofre justas críticas.

Por sua vez, desde a edição das primeiras leis, a evolução e transformação do direito das sucessões também foram bastante intensas. Originariamente, não se cogitou da sucessão causa mortis. Pertencendo os bens ao grupo e não ao indivíduo, a morte de uma pessoa não alterava seu status jurídico (do bem). Com o surgimento do caráter familiae da

\footnotetext{
${ }^{12}$ Ibid. p. 30.
} 
propriedade, desenvolveu-se a idéia de continuação do novo chefe do grupo com os bens que se achavam sob a direção do chefe pré-morto. A idéia de sucessão causa mortis somente ganhou campo com o surgimento da propriedade individual. E é necessariamente relacionada aos conceitos de família e de culto, presentes na Cidade Antiga. ${ }^{13}$

A renomada obra de Fustel de Coulanges assim esclarece:

"O direito de propriedade, tendo-se estabelecido para a efetivação de um culto hereditário, não podia extinguir-se a cabo da curta vida do indivíduo. $O$ homem morre, o culto fica; o lar nunca deve apagar-se nem o túmulo ficar abandonado. Persistindo a religião doméstica, com ela continua existindo o direito de propriedade. Duas coisas vivem estreitamente ligadas entre si, tanto nas crenças como nas leis dos antigos: o culto e a propriedade de uma mesma família. Por isso verificamos ser regra sem exceção, tanto no direito grego como no romano, não se pode adquirir a propriedade isoladamente do culto, nem o culto fora da propriedade. Deste princípio derivaram todas as regras do direito de sucessão entre os antigos. A primeira está em que, sendo a religião doméstica hereditária, de varão em varão, a propriedade igualmente o era. Deste modo se encontrou o princípio da hereditariedade. A continuação da propriedade, como a do culto, é para o filho uma obrigação tanto como um direito." 14

Desta maneira, o fundamento da sucessão causa mortis, antes de ser econômico, era religioso. Os bens transmitiam-se do de cujus ao herdeiro como um instrumento de devoção aos deuses domésticos, e também como meio de continuar na descendência a religião dos ascendentes. $\mathrm{O}$ surgimento da unidade da família e da autoridade do seu chefe passaram a concorrer na transmissão do pleno direito e na criação do testamento.

Depois, a sucessão causa mortis desenvolveu-se em outro sentido, mais ligado à continuação da vida do de cujus, que é feita a partir da continuação patrimonial. Em Roma, a morte do pater familias autorizava os herdeiros a ter direito à sucessão, mas também podia o de cujus indicar os seus sucessores - diferenciando-se, desta forma, as duas modalidades de sucessão: $a b$ intestato e a designação per testamentum, para distinguir a

\footnotetext{
${ }^{13}$ PEREIRA, Caio Mário da Silva. Instituições de Direito Civil. Vol. VI. $16^{\text {a }}$ Ed. Rio de Janeiro: Forense, 2007. p. 4.

${ }^{14}$ COULANGES, Fustel de. A Cidade Antiga. $4^{\text {a }}$ Ed. São Paulo: Martins Fontes, 2000. p. 69
} 
situação daquele que falece sem testamento e a do que deixa declaração de última vontade. ${ }^{15}$

Para se entender verdadeiramente a hereditariedade entre os antigos, devemos ter a imagem de haveres passando da mão de um homem para a mão de outro homem (homem, neste caso, exclusivamente no sentido masculino). É neste caso que as leis antigas se mostram extremamente injustas.

É gerada certa surpresa quando, no direito romano, se vê a filha casada não herdar do pai, e quando, no direito grego, vemos a mesma filha em caso algum herdar. Mas todas essas leis derivam não da lógica e da razão, ou do sentimento de eqüidade, mas das crenças e da religião que comandam as almas. ${ }^{16}$

O direito de fazer testamento, ou seja, o direito de dispor sobre os próprios bens para depois da morte, fazendo-os passar a outras pessoas que não o herdeiro natural, estava em conflito com aquelas crenças religiosas, base do direito de propriedade e do direito de sucessão. Além disso, a propriedade não pertencia ao indivíduo, mas à família da qual o indivíduo era parte; o homem não adquiria a propriedade pelo direito do trabalho, mas pelo culto doméstico. Ligada à família, a propriedade transmitia-se do morto para o vivo, não segundo a escolha e a vontade do de cujus, mas por força de regras superiores preestabelecidas na religião. ${ }^{17}$

Com o passar do tempo, tem-se a noção de que riqueza social é dedução de riqueza individual. A conservação e transferência de bens pela sucessão interessam ao mesmo tempo ao indivíduo e à sociedade. No direito moderno, o conceito de sucessão se difere do conceito presente na Cidade Antiga. Nos tempos mais remotos, a posse e a transferência patrimonial envolviam condições de chefia e de autoridade na família, em

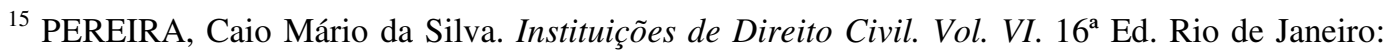
Forense, 2007. p. 5.

${ }^{16}$ COULANGES, Fustel de. A Cidade Antiga. $4^{\mathrm{a}}$ Ed. São Paulo: Martins Fontes, 2000. p. 71.

${ }^{17}$ Ibid. p. 79.
} 
que o direito romano se espelhou. Mais tarde, Roma assimila o espiritualismo cristão, com reflexo no seu direito.

No direito moderno, a propriedade, sendo individual, é assegurada aos membros do grupo familiar, não porque a todos pertence em comum, mas em razão do princípio da solidariedade, que fundamenta deveres de assistência do pai aos filhos, e por extensão a outros membros da família, bem como do filho ao pai. ${ }^{18}$ A transmissão hereditária visa proporcionar aos descendentes a propriedade do antecessor, segundo o princípio da afeição real ou presumida, que respectivamente informa a sucessão legítima e a testamentária. ${ }^{19}$

\subsection{O SURGIMENTO DO BIODIREITO COMO UM NOVO RAMO JURÍDICO}

Para Francisco Amaral, o Biodireito nada mais é do que um fértil processo de mudanças jurídicas, impostas pelos problemas da sociedade tecnológica, que tornou extremamente complexo o relacionamento social e impôs crescentes desafios às estruturas herdadas do século XIX. A resposta a esses desafios exige dos juristas e, particularmente, dos atuais civilistas, um esforço de reflexão profunda que lhes permita, a partir do conhecimento do direito brasileiro na sua origem e evolução, elaborar novos modelos que atendam às necessidades crescentes da sociedade contemporânea. ${ }^{20}$

Assim entende Jussara Suzi Assis Borges Nasser Ferreira:

"Com efeito, realmente, torna-se inarredável a intervenção do direito no campo das biotecnologias e biomédicas, considerando a gama de valores a merecer tutela jurídica capaz de equilibrar de um lado as portentosas descobertas científicas, e de outro o emprego de tais descobertas pela

\footnotetext{
${ }^{18}$ PEREIRA, Caio Mário da Silva. Instituições de Direito Civil. Vol. VI. $16^{\mathrm{a}}$ Ed. Rio de Janeiro: Forense, 2007. p. 6.

${ }^{19}$ Ibid. P. 6.

${ }^{20}$ AMARAL, Francisco. A Visão do Biodireito. In: Anais do Encontro regional do Simpósio de Bioética e Biodireito. 1997, p. 12.
} 
biomedicina, sem violar direitos, muitos dos quais, devidamente protegidos, como por exemplo, vários dos que integram o rol dos direitos da personalidade. ${ }^{, 1}$

O biodireito, como um novo ramo do direito atual, surgiu com o desenvolvimento da biotecnologia. O termo biotecnologia, por sua vez, pode ser definido como o conjunto de métodos aplicáveis às atividades que associam a complexidade dos organismos e seus derivados, conciliadas às constantes inovações tecnológicas. ${ }^{22}$ Define-se também pelo uso de conhecimentos sobre os processos biológicos e sobre as propriedades dos seres vivos, com o fim de resolver problemas e criar produtos de utilidade. ${ }^{23}$

Conforme elucida o mestre Caio Mário da Silva Pereira, a ciência biológica tem estreita relação com o mundo jurídico:

"Quando a ciência biológica anuncia processo de inseminação artificial, para proporcionar a gestação sem o pressuposto fisiológico das relações sexuais, uma série de implicações jurídicas eclode, como seja a indagação da legitimidade do filho, a necessidade de autorização da mulher, a anuência do marido, o registro do filho, afora o problema da inseminação contra a vontade de qualquer dos cônjuges, ou a sua realização sem o conhecimento do fato por algum deles, ou a necessidade de reconhecimento ou declaração da paternidade.

Estudos recentes na Doutrina Brasileira enfrentam com coragem aspectos jurídicos relevantes relativos ao tema. A ausência de uma regulamentação legal impõe o desafio ao jurista de participar das avaliações científicas indicando os elementos ético-jurídicos que deverão orientar a pesquisa. Não deve ser ele, apenas, um mero elaborador de normas proibitivas. ${ }^{24}$

Desta forma, a enorme evolução ocorrida no campo da biotecnologia acabou produzindo reflexos nas estruturas familiares, especialmente no que

\footnotetext{
21 FERREIRA, Jussara Suzi Assis Borges Nasser. Bioética e Biodireito. Disponível em <www.uel.br/dir/pos/publicacoes/pubjussaraf.html.>. Acesso em 18 jul. 2008.

${ }^{22}$ Disponível em <http://www.brasilescola.com/biologia/biotecnologia.htm>. Acesso em 4 jun. 2008.

${ }^{23}$ Disponível em < http://pt.wikipedia.org/wiki/Biotecnologia >. Acesso em 4 jun. 2008.

${ }^{24}$ PEREIRA, Caio Mário da Silva. Instituições de Direito Civil. Vol. V. 16 ${ }^{\mathrm{a}}$ Ed. Rio de Janeiro: Forense, 2006. pág. 9.
} 
diz respeito ao surgimento das novas formas de filiação. Os avanços tecnológicos na área da reprodução humana aumentaram significativamente a importância da vontade, fazendo com que todo o sistema de presunção de paternidade, da maternidade e da filiação desmoronasse.

Os inúmeros e imprevistos problemas jurídicos gerados pela acelerada evolução da biotecnologia e da biomedicina devem ter, como embasamento para obter respostas de imediato, o direito já existente. Os sucessivos desenvolvimentos nos diferentes ramos da atividade socioeconômica, tecnológica e científica exigem soluções jurídicas que desafiam sistemas, como o nosso, construídos no fim do século XIX, que evidentemente não atendem às necessidades contemporâneas. Tais soluções nascem gradativamente, mediante legislação especial, norteadas por princípios próprios, em harmonia com o ordenamento vigente ao qual devem se juntar. ${ }^{25}$

Os juristas brasileiros assistiram ao crescimento de inovações, tendo à disposição somente legislação destinada à família existente no fim do século XIX e que, a muito custo, veio sendo adaptada à realidade social em que vivemos.

Se de um lado as técnicas de reprodução assistida confrontaram os conceitos de início da vida e da sua proteção jurídica, de outro os transplantes de órgãos e tecidos e a possibilidade de prolongamento da vida colocaram em xeque o conceito de morte. ${ }^{26}$

O surgimento dessas situações faz com que o biodireito, pouco a pouco, se afirme, reunindo doutrina, legislação e jurisprudência próprias, regulando a conduta humana tendo em vista os avanços da biotecnologia e da biomedicina.

Cabe ao direito, por meio da lei, definir a ordem social, na medida em que dispõe dos meios próprios e adequados para que essa ordem seja

\footnotetext{
${ }^{25} \mathrm{Ibid}$

${ }^{26} \mathrm{Ibid}$.
} 
respeitada. Contudo, em alguns casos essa significação é dificultada porque certos princípios estruturais do direito são fundados na representação implícita do destino biológico do homem como a indisponibilidade do corpo ou a fronteira entre as pessoas e as coisas, o que não é mais fundamentalmente ajustável com o novo domínio do homem sobre os seres humanos. $^{27}$

Considerando que a maioria dos fatos a serem regulamentados pelo biodireito é inédita, ou seja, não cogitados pelo ordenamento em sua formulação original, torna-se necessária a constante observância dos princípios vigentes, preservando-se os valores escolhidos pela sociedade.

O objeto do biodireito é, portanto uma matéria complicada que afronta normas existentes que, na maioria das vezes, lhe são estranhas.

Pode-se afirmar, contudo, que sua base de princípios está construída. Os princípios constitucionais compreendem os valores primordiais de nossa sociedade, demonstrando, em sua maioria, direitos fundamentais do homem. Por sua natureza os princípios constitucionais devem constituir os princípios do biodireito. Em conseqüência, não poderão as regras do biodireito preterir esses princípios.

Portanto, se de um lado a existência de princípios já consolidados facilita de algum modo o trabalho do legislador, do intérprete e do aplicador do biodireito, de outro, a diversidade da matéria, sua extrema complexidade e sua larga abrangência, sem dúvida, vão lhe exigir profundo conhecimento da ciência e do sistema jurídicos que poderão fornecer elementos para as soluções mais adequadas. ${ }^{28}$

\footnotetext{
27 Ibid.

28 BARBOZA, Heloisa Helena. Princípios do Biodireito. In. Novos Temas de Biodireito e Bioética. Org. Heloisa Helena Barboza et al. Rio de Janeiro: Renovar, 2005. p. 49.
} 


\section{Capítulo ll}

\section{As TéCnicas de Reprodução Humana Assistida (RHA)}

\subsection{CONSIDERAÇÕES INICIAIS}

As técnicas de reprodução humana artificial evoluíram rapidamente, fato este que despertou vários segmentos da sociedade diante dos conflitos jurídicos (além de éticos) gerados. A rapidez desse progresso atropelou a reflexão sobre algumas sólidas instituições jurídicas. ${ }^{29}$

Somos surpreendidos, a cada dia, com novas técnicas reprodutivas e o impacto social é enorme e traz tanto conseqüências no âmbito individual como no coletivo, atingindo a humanidade.

O desejo de formar uma família e ter filhos é um desejo quase que absolutamente de qualquer casal (com raras exceções). No entanto, um em cada seis casais no mundo ocidental apresenta problemas de fertilidade e para $20 \%$ desses casais, o único modo de tratamento são as técnicas de reprodução humana assistida (RHA). ${ }^{30}$

Reprodução humana assistida é um conjunto de técnicas utilizadas por médicos especializados, que têm por principal objetivo viabilizar a gestação em mulheres com dificuldades de engravidar. ${ }^{31}$

As técnicas de reprodução humana assistida permitem a concepção da vida, sem a necessidade do ato sexual, por método artificial, científico ou técnico. A fecundação, resultante de reprodução medicamente assistida, é utilizada em substituição à concepção natural, quando houver dificuldade

\footnotetext{
${ }^{29}$ FERNANDES, Silvia da Cunha. As Técnicas de Reprodução Humana Assistida e a Necessidade de sua Regulamentação Jurídica. Rio de Janeiro: Renovar, 2005. p. 5.

${ }^{30}$ PETRACCO, Álvaro et al. Bioética e Reprodução assistida. In: Grandes temas da atualidade: Bioética e Biodireito. Coord. Eduardo de Oliveira Leite. Rio de Janeiro: Forense, 2004.

${ }^{31}$ Disponível em <http://www.ghente.org/temas/reproducao/index.htm>. Acesso em 28 ago. 2008.
} 
ou impossibilidade de um ou de ambos de gerar. São técnicas de interferência no processo natural, daí o nome de reprodução assistida. ${ }^{32}$

\subsection{EVOLUÇÃo HISTÓRICA DAS TÉCNICAS DE REPRODUÇÃo ASSISTIDA ${ }^{33}$}

A esterilidade humana sempre foi considerada como um grande problema e, por outro lado, a fertilidade sempre foi vista como uma bênção, como uma forma de "imortalidade".

Até o final do século XV, somente a mulher era considerada estéril, sendo inconcebível a admissão de esterilidade do homem. Somente no século XVII foi admitido que o homem também pudesse ser estéril.

No final do século XIX, pesquisadores concluíram que a fertilização se dava com a união de um espermatozóide com um óvulo através da relação sexual.

Somente no século XX, com o conhecimento médico mais avançado, é que foram realizadas grandes descobertas no campo da genética e a década de 1970 foi decisiva para a evolução da reprodução artificial.

Em 1953, os cientistas ingleses James B. Watson e Francis H. C. Crick descobriram a estrutura do DNA, descoberta esta considerada como o marco inicial da engenharia genética.

Entre 1970 e 1975, diversos cientistas realizaram estudos sobre a fertilização in vitro com óvulos humanos, mas foi no final da década de 1970 que o primeiro bebê de proveta nasceu na Inglaterra. Após numerosos estudos, o cientista R.G. Edwards e sua equipe viram nascer, em 1978, no

\footnotetext{
${ }^{32}$ PETRACCO, Álvaro et al. Bioética e Reprodução assistida. In: Grandes temas da atualidade: Bioética e Biodireito. Coord. Eduardo de Oliveira Leite. Rio de Janeiro: Forense, 2004.

${ }^{33}$ Informações retiradas de: FERNANDES, Silvia da Cunha. As Técnicas de Reprodução Humana Assistida e a Necessidade de sua Regulamentação Jurídica. Rio de Janeiro: Renovar, 2005. p. 23.
} 
Oldham General Hospital, em Manchester, Louise Brown, o primeiro bebê de proveta a vir à luz na história da humanidade. ${ }^{34}$

Atualmente, para quase todos os tipos de esterilidade existe uma técnica apropriada. As mais usuais trataremos em seguida.

\subsection{As TÉCNICAS de Reprodução Humana Assistida}

As técnicas, quanto ao meio de inseminação, se dividem em dois grupos: as intracorpóreas (técnicas que otimizam o encontro dos gametas dentro do organismo feminino) e as extracorpóreas (técnicas de ectogênese, nas quais o encontro dos gametas é feito em laboratório).

Classificando quanto à origem do material reprodutivo, as técnicas podem ser de três espécies: homóloga, heteróloga ou de "mistura bisseminal”.

Na homóloga, o material procede do próprio casal, ou seja, a paternidade jurídica corresponde à paternidade biológica, uma vez que o material reprodutivo (sêmen e óvulos) pertence aos envolvidos no projeto parental, e, portanto, quem fornece o material reprodutivo é o casal que pretende ser pais.

Já as técnicas de reprodução humana assistida heterólogas são aquelas em que o material reprodutivo é doado. Quando a concepção é feita com material genético de outrem que não os que têm a intenção de ser pais, o vínculo de filiação é estabelecido com a mãe e, sendo ela casada, o marido será o pai por presunção legal, se este consentiu com a prática da inseminação. ${ }^{35}$

\footnotetext{
${ }^{34}$ FRASÃO, Alexandre Gonçalves. A fertilização "in vitro": uma nova problemática jurídica. Retirado do site <www.jus.com.br>. Acesso em 20 set. 2008.

${ }^{35}$ DIAS, Maria Berenice. Manual de Direito das Famílias. São Paulo: Revista dos Tribunais, 2007. p. 329.
} 
E na "bisseminal” (quando há insuficiência de espermatozóides na ejaculação) é processada uma mistura diluindo-se partes do esperma do marido ou companheiro e do doador. ${ }^{36}$

Nos casos discutidos aqui trataremos exclusivamente da técnica de fecundação artificial homóloga, pois através da concepção post mortem é utilizado o material genético do casal, com a particularidade de que um dos genitores já se encontra falecido no momento da fecundação. E, obviamente, no caso de implantação embrionária póstuma, trata-se também de técnica homóloga, uma vez que o material utilizado para a criação dos embriões é de ambos os pais.

Para melhor ilustrar a presente tese monográfica, a seguir trataremos das mais comuns modalidades técnicas de reprodução humana assistida.

\subsubsection{INSEMINAÇÃO INTRA-UTERINA (IIU)}

A Inseminação Intra-uterina (IIU) é um processo simples, que visa otimizar a gravidez e consiste na tentativa de fecundar uma mulher, por via diferente da relação sexual, introduzindo o sêmen no interior do seu aparelho reprodutor.

A Inseminação Intra-uterina reproduz as condições fisiológicas da relação sexual. Consiste, portanto, na introdução do sêmen no útero (no canal cervical ou peritonal) da genitora e tanto a fecundação como a formação do zigoto se fazem dentro do corpo da mulher. Dependendo do local onde é feita a depositação dos espermatozóides, pode ser: intra cervical, intra-uterina ou intra peritonal. ${ }^{37}$

\footnotetext{
${ }^{36}$ PÁDUA, Amélia do Rosário Motta de. Responsabilidade Civil na Reprodução Assistida. Rio de Janeiro: Lúmen Júris, 2008. p. 72.

${ }^{37}$ Ibid. p. 73.
} 


\subsubsection{TRANSFERÊnCIA INTRAFALOPIANA DE GAMETAS (GIFT)}

A Transferência Intrafalopiana de Gametas (GIFT - Gamet IntraFalopean Transfer) consiste na introdução do sêmen nas trompas de falópio e a fecundação é também natural. Consiste em obter os oócitos e os espermatozóides (gametas) para serem introduzidos nas trompas para que ali - onde ocorre naturalmente a fecundação - possa acontecer o processo de fertilização. ${ }^{38}$

\subsubsection{FERTILIZAÇÃo IN VITRO (FIVETE)}

A Fertilização In Vitro (FIVETE) é uma técnica que consiste em extrair o óvulo maduro de dentro do ovário da mulher (estimulando-se a superovulação) e o sêmen do genitor e, em laboratório (estufa), ocorre a fecundação e formam-se os zigotos (pré-embriões). Os óvulos fecundados (embriões) são transferidos para o útero da mulher, sendo esta a fase mais imprevisível do procedimento.

A técnica, atualmente, tem as seguintes fases: a) Tratamento hormonal da mulher - para provocar um aumento na produção de oócitos; b) Coleta de oócitos; c) Fecundação in vitro (FIVETE) - colocação dos oócitos em contato com os espermatozóides, para que o processo de fecundação se realize em laboratório; e d) Transferência embrionária - fase final em que o embrião é transferido para o interior do útero, onde realiza por si só o processo de implantação e continua seu desenvolvimento embrionário. ${ }^{39}$

\footnotetext{
${ }^{38}$ Ibid. p. 73.

${ }^{39}$ Ibid. p. 73 .
} 


\subsubsection{TRANSFERÊNCIA INTRAFALOPIANA DE ZIGOTO (ZIFT).}

A Transferência Intrafalopiana de Zigoto (ZIFT - Zigot IntraFalopean Transfer) consiste em realizar os mesmos procedimentos preparatórios da fertilização in vitro (FIVETE), mas os zigotos são transferidos para as trompas de falópio. ${ }^{40}$

\subsection{CONSIDERAÇÕES ACERCA DO MATERIAL REPRODUTIVO}

No caso das técnicas de Ectogênese, os embriões concebidos através de manipulação genética que não são implantados no ventre de uma mulher são chamados de embriões excedentários. De um modo geral, nos procedimentos de fertilização in vitro, são gerados vários embriões, tendo sido realizadas diversas tentativas de concepção. Os embriões descartados e não utilizados permanecem armazenados na clínica que procedeu a fertilização. Ou seja, quando a técnica empregada é a Fecundação In Vitro (FIVETE) ou a Transferência Intrafalopiana de Zigoto (ZIFT), o médico produz um grande número de embriões a partir dos óvulos e espermatozóides doados. Somente alguns desses embriões serão implantados no útero materno, os demais serão mantidos congelados (criopreservados), para utilização posterior, caso seja necessário.

As questões referentes aos embriões excedentários podem gerar delicados problemas acerca do direito de personalidade, havendo o risco de serem reconhecidos os embriões como nascituros, bem como sujeitos de direitos. A polêmica com relação à bioética e ao biodireito é muito grande e a questão continua gerando inúmeras controvérsias.

\footnotetext{
${ }^{40}$ Ibid. p. 74.
} 
No Brasil, não existe lei regulando a reprodução humana assistida. Há, no entanto, a Lei de Biossegurança (Lei 11.105/2005) ${ }^{41}$, que admite a pesquisa com embriões com mais de três anos de congelamento, uma vez que seriam diagnosticados como impróprios para a vida. A referida lei, em seu artigo $5^{\circ}$, prevê o seguinte:

"Art. $5^{\circ}$. É permitida, para fins de pesquisa e terapia, a utilização de célulastronco embrionárias obtidas de embriões humanos produzidos por fertilização in vitro e não utilizados no respectivo procedimento, atendidas as seguintes condições:

I - sejam embriões inviáveis; ou

II - sejam embriões congelados há 3 (três) anos ou mais, na data da publicação desta Lei, ou que, já congelados na data da publicação desta Lei, depois de completarem 3 (três) anos, contados a partir da data de congelamento.

$\S 1^{\circ}$ Em qualquer caso, é necessário o consentimento dos genitores.

$\S 2^{\circ}$ Instituições de pesquisa e serviços de saúde que realizem pesquisa ou terapia com células-tronco embrionárias humanas deverão submeter seus projetos à apreciação e aprovação dos respectivos comitês de ética em pesquisa.

$\S 3^{\circ}$ É vedada a comercialização do material biológico a que se refere este artigo e sua prática implica o crime tipificado no art. 15 da Lei no 9.434, de 4 de fevereiro de 1997."

Na Ação Direta de Inconstitucionalidade (ADI/3510) proposta pelo Procurador Geral da República contra o citado art. $5^{\circ}$ da Lei de Biossegurança, o Supremo Tribunal Federal, em julgamento de grande repercussão, decidiu, em maio de 2008, o seguinte:

"Em conclusão, o Tribunal, por maioria, julgou improcedente pedido formulado em ação direta de inconstitucionalidade proposta pelo ProcuradorGeral da República contra o art. $5^{\circ}$ da Lei federal 11.105/2005 (Lei da Biossegurança), que permite, para fins de pesquisa e terapia, a utilização de células-tronco embrionárias obtidas de embriões humanos produzidos por fertilização in vitro e não usados no respectivo procedimento, e estabelece condições para essa utilização. Prevaleceu o voto do Min. Carlos Britto, relator. Nos termos do seu voto, salientou, inicialmente, que o artigo impugnado seria um bem concatenado bloco normativo que, sob condições de incidência explícitas, cumulativas e razoáveis, contribuiria para o desenvolvimento de linhas de pesquisa científica das supostas propriedades terapêuticas de células extraídas de embrião humano in vitro. Esclareceu que as células-tronco embrionárias,

${ }^{41}$ DIAS, Maria Berenice. Manual de Direito das Famílias. São Paulo: Revista dos Tribunais, 2007. p. 329. 
pluripotentes, ou seja, capazes de originar todos os tecidos de um indivíduo adulto, constituiriam, por isso, tipologia celular que ofereceria melhores possibilidades de recuperação da saúde de pessoas físicas ou naturais em situações de anomalias ou graves incômodos genéticos. Asseverou que as pessoas físicas ou naturais seriam apenas as que sobrevivem ao parto, dotadas do atributo a que o art. $2^{o}$ do Código Civil denomina personalidade civil, assentando que a Constituição Federal, quando se refere à "dignidade da pessoa humana" (art. 1", III), aos "direitos da pessoa humana” (art. 34, VII, b), ao "livre exercício dos direitos... individuais" (art. 85, III) e aos "direitos e garantias individuais" (art. 60, $\$ 4^{\circ}, I V$ ), estaria falando de direitos e garantias do indivíduo-pessoa. Assim, numa primeira síntese, a Carta Magna não faria de todo e qualquer estádio da vida humana um autonomizado bem jurídico, mas da vida que já é própria de uma concreta pessoa, porque nativiva, e que a inviolabilidade de que trata seu art. $5^{\circ}$ diria respeito exclusivamente a um indivíduo já personalizado.

$O$ relator reconheceu, por outro lado, que o princípio da dignidade da pessoa humana admitiria transbordamento e que, no plano da legislação infraconstitucional, essa transcendência alcançaria a proteção de tudo que se revelasse como o próprio início e continuidade de um processo que desaguasse no indivíduo-pessoa, citando, no ponto, dispositivos da Lei 10.406/2002 (Código Civil), da Lei 9.434/97, e do Decreto-lei 2.848/40 (Código Penal), que tratam, respectivamente, dos direitos do nascituro, da vedação à gestante de dispor de tecidos, órgãos ou partes de seu corpo vivo e do ato de não oferecer risco à saúde do feto, e da criminalização do aborto, ressaltando, que o bem jurídico a tutelar contra o aborto seria um organismo ou entidade pré-natal sempre no interior do corpo feminino. Aduziu que a lei em questão se referiria, por sua vez, a embriões derivados de uma fertilização artificial, obtida fora da relação sexual, e que o emprego das células-tronco embrionárias para os fins a que ela se destina não implicaria aborto. Afirmou que haveria base constitucional para um casal de adultos recorrer a técnicas de reprodução assistida que incluísse a fertilização in vitro, que os artigos 226 e seguintes da Constituição Federal disporiam que o homem e a mulher são as células formadoras da família e que, nesse conjunto normativo, estabelecer-se-ia a figura do planejamento familiar, fruto da livre decisão do casal e fundado nos princípios da dignidade da pessoa humana e da paternidade responsável (art. 226, $\S 7^{\circ}$ ), inexistindo, entretanto, o dever jurídico desse casal de aproveitar todos os embriões eventualmente formados e que se revelassem geneticamente viáveis, porque não imposto por lei $\left(\mathrm{CF}\right.$, art. $\left.5^{\circ}, \mathrm{II}\right)$ e incompatível com o próprio planejamento familiar.

O Min. Cezar Peluso julgou improcedente o pedido, ressaltando, porém, que dava interpretação conforme à Constituição aos artigos relativos aos embriões na legislação impugnada, para os fins que declarou. No que se refere à inteligência das expressões "para fins de pesquisa e terapia" e "pesquisa ou terapia” contidas no art. $5^{\circ}$, caput, e $\$ 2^{\circ}$, afirmou que a autorização exclusiva de uso de células-tronco embrionárias em pesquisas deveria ser para fins exclusivamente terapêuticos.

O Min. Menezes Direito propôs o que se segue: 1) no caput do art. $5^{\circ}$, declarar parcialmente a inconstitucionalidade, sem redução de texto, dando interpretação conforme a Constituição, para que seja entendido que as célulastronco embrionárias sejam obtidas sem a destruição do embrião e as pesquisas, devidamente aprovadas e fiscalizadas pelo órgão federal, com a participação de 
especialistas de diversas áreas do conhecimento, entendendo-se as expressões "pesquisa" e "terapia" como pesquisa básica voltada para o estudo dos processos de diferenciação celular e pesquisas com fins terapêuticos; 2) também no caput do art. $5^{\circ}$, declarar parcialmente a inconstitucionalidade, sem redução do texto, para que a fertilização in vitro seja entendida como modalidade terapêutica para cura da infertilidade do casal, devendo ser empregada para fins reprodutivos, na ausência de outras técnicas, proibida a seleção de sexo ou características genéticas; realizada a fertilização de um máximo de 4 óvulos por ciclo e igual limite na transferência, com proibição de redução embrionária, vedado o descarte de embriões, independentemente de sua viabilidade, morfologia ou qualquer outro critério de classificação, tudo devidamente submetido ao controle e fiscalização do órgão federal; 3) no inciso I, declarar parcialmente a inconstitucionalidade, sem redução de texto, para que a expressão "embriões inviáveis" seja considerada como referente àqueles insubsistentes por si mesmos, assim os que comprovadamente, de acordo com as normas técnicas estabelecidas pelo órgão federal, com a participação de especialistas em diversas áreas do conhecimento, tiveram seu desenvolvimento interrompido, por ausência espontânea de clivagem, após período, no mínimo, superior a 24 horas, não havendo, com relação a estes, restrição quanto ao método de obtenção das células-tronco; 4) no inciso II, declarar a inconstitucionalidade, sem redução de texto, para que sejam considerados embriões congelados há 3 anos ou mais, na data da publicação da Lei 11.105/2005, ou que, já congelados na data da publicação dessa lei, depois de completarem 3 anos de congelamento, dos quais, com o consentimento informado, prévio e expresso dos genitores, por escrito, somente poderão ser retiradas células-tronco por meio que não cause sua destruição; 5) no $\$ 1^{o}$, declarar parcialmente a inconstitucionalidade, sem redução de texto, para que seja entendido que o consentimento é um consentimento informado, prévio e expresso por escrito pelos genitores; 6) no $\S 2^{\circ}$, declarar a inconstitucionalidade, sem redução de texto, para que seja entendido que as instituições de pesquisa e serviços de saúde que realizem pesquisa com terapia com células-tronco embrionárias humanas deverão submeter, previamente, seus projetos também à aprovação do órgão federal, sendo considerado crime a autorização da utilização de embriões em desacordo com o que estabelece esta decisão, incluídos como autores os responsáveis pela autorização e fiscalização. Por fim, conferiu à decisão efeitos a partir da data do julgamento final da ação, a fim de preservar resultados e pesquisas com células-tronco embrionárias já obtidas por pesquisadores brasileiros.

O Min. Ricardo Lewandowski julgou procedente, em parte, o pleito para, sem redução de texto, conferir a seguinte interpretação aos dispositivos discriminados, com exclusão de qualquer outra: 1) art. $5^{\circ}$, caput: as pesquisas com células-tronco embrionárias somente poderão recair sobre embriões humanos inviáveis ou congelados logo após o início do processo de clivagem celular, sobejantes de fertilizações in vitro realizadas com o fim único de produzir o número de zigotos estritamente necessário para a reprodução assistida de mulheres inférteis; 2) inciso I do art. $5^{\circ}$ : o conceito de "inviável" compreende apenas os embriões que tiverem o seu desenvolvimento interrompido por ausência espontânea de clivagem após periodo superior a 24 horas contados da fertilização dos oócitos; 3) inciso II do art. $5^{\circ}$ : as pesquisas com embriões humanos congelados são admitidas desde que não sejam destruídos nem tenham o seu potencial de desenvolvimento comprometido; 4) $\S 1^{o}$ do art. $5^{o}$ : a realização de pesquisas com as células-tronco embrionárias exige o consentimento "livre e informado" dos genitores, formalmente exteriorizado; 5) $\S 2^{\circ}$ do art. $5^{\circ}$ : os projetos de experimentação com embriões humanos, além de 
aprovados pelos comitês de ética das instituições de pesquisa e serviços de saúde por eles responsáveis, devem ser submetidos à prévia autorização e permanente fiscalização dos órgãos públicos mencionados na lei impugnada.

O Min. Gilmar Mendes, Presidente, julgou improcedente a ação, para declarar a constitucionalidade do art. $5^{\circ}$, seus incisos e parágrafos, da Lei 11.105/2005, desde que seja interpretado no sentido de que a permissão da pesquisa e terapia com células-tronco embrionárias, obtidas de embriões humanos produzidos por fertilização in vitro, deve ser condicionada à prévia autorização e aprovação por Comitê (Órgão) Central de Ética e Pesquisa, vinculado ao Ministério da Saúde." 42 (grifos nossos)

Conclui-se, portanto, que o Supremo Tribunal Federal abraçou o entendimento de que não se pode ignorar a evolução da biotecnologia no que diz respeito à questão do material reprodutivo excedentário. Esse foi um grande avanço, tendo em vista os preconceitos infelizmente ainda presentes em nossa sociedade.

Acerca da regulamentação específica da reprodução humana assistida, o Poder Legislativo ainda não avançou e, portanto, não há lei que trate do assunto (veremos mais a frente projetos de lei concernentes ao assunto).

Contudo, atualmente, há a Resolução CFM n. 1.358/92 do Conselho Federal de Medicina ${ }^{43}$ (norma deontológica), que dispõe sobre os princípios gerais que devem nortear a utilização de qualquer das técnicas de reprodução humana assistida, dando ênfase ao consentimento informado e proibindo a fecundação com outra finalidade que não a reprodução humana.

De acordo com a citada Resolução, os embriões criopreservados não podem ser destruídos ou descartados, devendo permanecer congelados por tempo indeterminado. O destino a ser dado a esses embriões caso ocorra divórcio, doença grave ou morte de um ou de ambos os cônjuges, deve ser anunciado previamente por escrito pelo casal. Mas, em alguns casos, as clínicas de reprodução humana assistida não têm o cuidado de fazer com que os genitores esclareçam qual o destino desejado para os embriões

\footnotetext{
${ }^{42}$ Disponível em <www.stf.gov.br>. Acesso em 14 set. 2008.

${ }^{43}$ A íntegra desta resolução encontra-se no Anexo I a esta obra.
} 
excedentários, principalmente no caso de morte, o que pode gerar situações complexas e praticamente sem solução.

Um exemplo claro é o que tratamos no presente trabalho, da possibilidade de a mulher se submeter ao procedimento de implantação de um embrião excedentário após a morte de seu marido (sem que este tenha deixado autorização por escrito). ${ }^{44} \mathrm{Ou}$ então, no caso de a mulher se submeter à concepção com sêmen congelado de seu marido ou companheiro já morto.

\footnotetext{
${ }^{44}$ Disponível em <http://www1.folha.uol.com.br/folha/ciencia/ult306u406822.shtml>. Acesso em
} 16 abr. 2008. 


\section{Capítulo III}

\section{A Vocação Hereditária e a INTERPREtaÇão dos Artigos 1.798 E 1.799 do Código CIVIL}

\subsection{Breve INTROdUÇão Ao Direito dAS SUCESSÕES}

$\mathrm{O}$ direito à herança é uma garantia fundamental do cidadão. $\mathrm{O}$ art. $5^{\circ}$, XXX, da Constituição Federal ${ }^{45}$ protege a propriedade privada, isto é, com a morte do proprietário, fica garantido aos seus herdeiros o recebimento do bem. $\mathrm{O}$ direito de herança tem dois pilares, um objetivo e outro subjetivo. Do ponto de vista objetivo, o direito de herança é funcional, ou seja, é baseado na propriedade privada. Já do ponto de vista subjetivo, quanto aos sujeitos da herança, o direito está baseado na família. Pontes de Miranda assinala que a sucessão legítima tem o seu fundamento na existência de um vínculo familiar, ou, na falta de elementos de família e de cláusula testamentária, de um vínculo estatal. ${ }^{46}$

Como prevê o Código Civil em seu artigo $1.786^{47}$, a sucessão darse-á por lei ou por disposição de última vontade. Ou seja, a sucessão é realizada através de duas formas, pela sucessão legítima e pela sucessão testamentária. A sucessão legítima ocorre por força de determinação legal e a sucessão testamentária por disposição de última vontade, através do testamento. O testamento, por sua vez, é o instrumento utilizado para se exercer o poder outorgado pelo Estado aos indivíduos para que regulem seus interesses post mortem, ou seja, é uma proteção à autonomia privada. E

\footnotetext{
${ }^{45}$ Art. $5^{\circ}$ Todos são iguais perante a lei, sem distinção de qualquer natureza, garantindo-se aos brasileiros e aos estrangeiros residentes no País a inviolabilidade do direito à vida, à liberdade, à igualdade, à segurança e à propriedade, nos termos seguintes: XXX - é garantido o direito de herança;

${ }^{46}$ NEVARES, Ana Luiza Maia. O Princípio da Intangibilidade da Legítima. In: Princípios do Direito Civil Contemporâneo. Coord. Maria Celina Bodin de Moraes. Rio de Janeiro: Renovar, 2006. p. 495.

${ }^{47}$ Art. 1.786. A sucessão dá-se por lei ou por disposição de última vontade.
} 
as duas formas de sucessão, legítima e testamentária, podem ser simultâneas.

A renomada civilista Maria Luiza Maia Nevares assim entende:

"A sucessão será legítima quando não houver testamento, quando este for julgado nulo ou caducar ou quando não esgotar o patrimônio do autor da herança. No entanto, as disposições testamentárias não poderão afastar a sucessão legítima quando houver herdeiros necessários." 48

Existem, portanto, dois tipos de herdeiros: os herdeiros necessários e os herdeiros facultativos. Herdeiros necessários são aqueles que não podem ser afastados da sucessão, salvo em caso de indignidade ou deserdação, e têm uma cota parte da herança reservada para si, como expõe o Código Civil em seu artigo $1.789^{49}$. São herdeiros necessários os descendentes, os ascendentes, o cônjuge e o companheiro (havendo extensas discussões quanto à necessariedade deste último); já os herdeiros facultativos são os parentes em linha colateral até o $4^{\circ}$ grau.

Portanto, podemos concluir que a sucessão legítima se divide em sucessão legítima necessária e sucessão legítima facultativa. A sucessão legítima necessária é aquela que não pode ser excluída pela vontade do de cujus, dando origem aos herdeiros necessários e à quota necessária, também denominada de legítima. Em contraposição a esta, há a quota disponível, ou seja, aquela parte do patrimônio que o de cujus pode dispor livremente. ${ }^{50}$

Por conta da sucessão legítima existem os sucessores legítimos previstos por lei, no Código Civil, artigo $1.829^{51}$. São estes os sucessores

\footnotetext{
${ }^{48}$ NEVARES, Ana Luiza Maia. O Princípio da Intangibilidade da Legítima. In: Princípios do Direito Civil Contemporâneo. Coord. Maria Celina Bodin de Moraes. Rio de Janeiro: Renovar, 2006. p. 496.

${ }^{49}$ Art. 1.789. Havendo herdeiros necessários, o testador só poderá dispor da metade da herança.

50 NEVARES, Ana Luiza Maia. O Princípio da Intangibilidade da Legítima. In: Princípios do Direito Civil Contemporâneo. Coord. Maria Celina Bodin de Moraes. Rio de Janeiro: Renovar, 2006. p. 496.

${ }^{51}$ Art. 1.829. A sucessão legítima defere-se na ordem seguinte:

I - aos descendentes, em concorrência com o cônjuge sobrevivente, salvo se casado este com o falecido no regime da comunhão universal, ou no da separação obrigatória de bens (art. 1.640,
} 
indicados pelo legislador para recolher os bens da herança, os descendentes, os ascendentes, o cônjuge e os parentes em linha colateral. As disposições testamentárias não podem ultrapassar a quota disponível e, por esta razão, serão reduzidas se atingirem a legítima dos herdeiros necessários. ${ }^{52}$

Os casos tratados no presente trabalho são acerca da sucessão legítima necessária, uma vez que se trata, em todos os casos, do direito de herdar do descendente (primeiro na linha sucessória), que vem a ser concebido (por meio de uma das técnicas de reprodução humana assistida) ou implantado (embrião já concebido por meio de fertilização in vitro feita em laboratório) após a morte do autor da herança.

\subsection{VocaÇão HEREDITÁRIA}

Como já exposto, a Constituição Federal de 1988, em seu art. $226 \S$ $7^{\circ}$, estabelece que o planejamento familiar é de livre decisão do casal, com base nos princípios da dignidade da pessoa humana e da paternidade responsável. Esta responsabilidade é de ambos os pais, cônjuges ou companheiros, sujeitos ativos na definição de prioridades nas relações familiares e no âmbito doméstico. ${ }^{53}$

O Código Civil, por sua vez, estabelece a vocação hereditária em seu artigo 1.798 e dispõe a respeito da possibilidade de serem chamados a suceder os filhos, ainda não concebidos, de pessoas indicadas pelo testador,

parágrafo único); ou se, no regime da comunhão parcial, o autor da herança não houver deixado bens particulares;

II - aos ascendentes, em concorrência com o cônjuge;

III - ao cônjuge sobrevivente;

IV - aos colaterais.

52 NEVARES, Ana Luiza Maia. O Princípio da Intangibilidade da Legítima. In: Princípios do Direito Civil Contemporâneo. Coord. Maria Celina Bodin de Moraes. Rio de Janeiro: Renovar, 2006. p. 495.

${ }^{53}$ PEREIRA, Caio Mário da Silva. Instituições de Direito Civil. Vol. V. 16 ${ }^{\mathrm{a}}$ Ed. Rio de Janeiro: Forense, 2006. p. 8. 
sob a condição de estarem vivas essas ao abrir-se a sucessão, em seu artigo 1.799 , inciso I.

"Art. 1.798. Legitimam-se a suceder as pessoas nascidas ou já concebidas no momento da abertura da sucessão."

“Art. 1.799. Na sucessão testamentária podem ainda ser chamados a suceder: I - os filhos, ainda não concebidos, de pessoas indicadas pelo testador, desde que vivas estas ao abrir-se a sucessão;

(...).”

O Código Civil brasileiro, portanto, mantém a distinção entre pessoa nascida, pessoa concebida e pessoa não concebida. E, desta forma, estabelece que a pessoa já concebida, bem como a prole eventual (pessoa não concebida), têm vocação hereditária (mesmo que testamentária no caso da prole eventual) e, por isso, no momento da morte do autor da herança têm direito a sucedê-lo. A questão que se põe é a seguinte: no caso de pessoa já concebida, estaríamos incluindo nesta categoria os embriões congelados?

Ao se responder a referida questão positivamente, estaríamos atribuindo aos embriões todos os direitos estabelecidos por lei aos nascituros. Assim não só direitos relativos à personalidade (como: direito à vida, à saúde, à imagem), mas também no tocante aos direitos patrimoniais, tais como a doação e a herança, que dependem do nascimento com vida para aperfeiçoar-se. Se desde a concepção, o representante legal do nascituro pode ingressar na posse dos bens doados ou herdados, como ficariam esses direitos na hipótese de se tratar de embriões congelados? ${ }^{54}$ É, portanto, esta a questão cerne que estamos tratando aqui.

\footnotetext{
${ }^{54}$ MEIRELLES, Jussara Maria Leal de. Os Embriões Humanos Mantidos em Laboratório e a proteção da pessoa: o novo Código Civil Brasileiro e o texto Constitucional. In: Novos Temas de Biodireito e Bioética. Org. Heloisa Helena Barboza et al. Rio de Janeiro: Renovar, 2000. p. 83.
} 
A primeira dúvida, portanto, é saber se os embriões congelados em laboratório devem ser considerados nascituros (filhos concebidos) ou o que se chama de prole eventual (filhos não concebidos). Reconhecidos como nascituros, os embriões congelados teriam personalidade jurídica e desfrutariam da qualidade de herdeiros - e herdeiros necessários (uma vez que são descendentes diretos do de cujus) - independente de quando fosse levada a efeito a implantação. Com o nascimento fariam jus ao quinhão hereditário e seus frutos desde a abertura da sucessão.

Considerados os embriões congelados como filhos eventuais, só poderiam ser incluídos como herdeiros testamentários e ficariam excluídos da sucessão do pai ou da mãe que não conheceram, mas a quem devem a paternidade biológica. É o que propõe Débora Gozzo e Sílvio Venosa: o emprego da analogia para assegurar o direito sucessório resultante das técnicas de reprodução assistida, da mesma maneira que se admite a nomeação de filho eventual. ${ }^{55}$

A opinião que vem prevalecendo na doutrina, contudo, é reconhecer o rompimento do testamento na hipótese de ocorrer a implantação e o posterior nascimento. ${ }^{56}$ Para a doutrina, duas são as causas que podem ensejar o rompimento do testamento: a inexistência e o desconhecimento da existência de herdeiro necessário quando da sua elaboração. ${ }^{57}$

No entanto, segundo a autora e magistrada do Rio Grande do Sul, Maria Berenice Dias, esta solução não pode prevalecer, pois não dá para se falar em ignorância do testador da existência de herdeiros necessários, tendo-se que levar em consideração o artigo 1.974 do Código Civil ${ }^{58}$. Na reprodução homóloga, o de cujus submeteu-se a procedimento laboratorial

\footnotetext{
${ }^{55}$ DIAS, Maria Berenice. Manual das Sucessões. São Paulo: Revista dos Tribunais, 2008. p. 326.

${ }^{56}$ Neste sentido: HIRONAKA, Giselda Maria Fernandes Novaes. Direito das Sucessões. $3^{\mathrm{a}}$ Ed. Rio de Janeiro: Revista dos Tribunais, 2007. p. 290, e RODRIGUES, Silvio. Direito Civil, v. 7. Direito das sucessões. 26 ${ }^{\mathrm{a}}$ Ed. São Paulo: Saraiva, 2006. p. 270.

${ }^{57}$ DIAS, Maria Berenice. Manual das Sucessões. São Paulo: Revista dos Tribunais, 2008. p. 468.

58 Art. 1.974. Rompe-se também o testamento feito na ignorância de existirem outros herdeiros necessários.
} 
em vida para a retirada de material genético (situação da qual estamos tratando) e na heteróloga, firmou documento autorizando a fecundação. ${ }^{59}$

A autora entende que a única solução que se assemelha - e que a um só tempo atende à vontade do testador e não exclui herdeiros necessários da sucessão - é reduzir as disposições testamentárias, como prevê o artigo 1.967 do Código Civil ${ }^{60}$, de modo a respeitar o quinhão do herdeiro necessário que venha a nascer depois da morte do genitor, mas com seu consentimento.

Nessas situações específicas, não há como impedir que sejam beneficiados os filhos do testador, exatamente em face das possibilidades de reprodução assistida. Ainda segundo o que defende parte da doutrina ${ }^{61}$, havendo material genético armazenado em laboratório, pode o seu proprietário nomeá-los como herdeiros eventuais.

Giselda Hironaka nega tal possibilidade, mas alerta que o testador pode obter o mesmo resultado por via reflexa, ao indicar quem irá submeter-se à técnica reprodutiva como genitor do herdeiro. Também admite ser possível a indicação do doador do óvulo ou do espermatozóide para a concepção da prole eventual. ${ }^{62}$

Demonstrado, assim, que são inconfundíveis as noções referentes ao nascituro (pessoa concebida) e à prole eventual (pessoa não concebida), a leitura do artigo $2^{\circ}$ do Código Civil ${ }^{63}$ pode demonstrar que a proteção legal da pessoa humana atinge o nascituro (pessoa concebida), exclui a prole eventual (pessoa ainda não concebida) e deixa à margem o embrião in vitro (pessoa também já concebida).

\footnotetext{
${ }^{59}$ DIAS, Maria Berenice. Manual das Sucessões. São Paulo: Revista dos Tribunais, 2008. p. 468.

${ }^{60}$ Art. 1.967. As disposições que excederem a parte disponível reduzir-se-ão aos limites dela, de conformidade com o disposto nos parágrafos seguintes.

${ }^{61}$ GOZZO, Débora. VENOSA, Sílvio de salvo. Comentários ao Código Civil brasileiro, v. XVI. Rio de Janeiro: Forense, 2004. p. 42.

${ }^{62}$ DIAS, Maria Berenice. Manual das Sucessões. São Paulo: Revista dos Tribunais, 2008. p. 326.

${ }^{63}$ Art. $2^{\circ}$. A personalidade civil da pessoa começa do nascimento com vida; mas a lei põe a salvo, desde a concepção, os direitos do nascituro.
} 
Poderíamos argumentar afirmando que o citado artigo $2^{\circ}$ dispõe que a lei põe a salvo, desde a concepção, os direitos do nascituro. Logo, podemos analogicamente concluir que os embriões de laboratório também estariam protegidos, uma vez que poderiam ser considerados também como nascituros para muitos autores. ${ }^{64}$

Tradicionalmente, a doutrina afirma que o conceito de nascituro só existe quando há gravidez, ou seja, após a denominada nidação, que é a implantação do novo ser no útero ${ }^{65}$. Em se tratando de fecundação in vitro é necessária a implantação no útero, para que ao novo ser seja atribuída a condição de pessoa natural.

Assim entende o autor Carlos Alberto Bittar:

"Nascituro é um conceito que só existe quando há gravidez; (...) destarte, também não é nascituro o embrião humano congelado (...) que, no entanto, deve ser protegido jurídica e eticamente como pessoa virtual" 66

Permitimo-nos aqui, discordar da doutrina tradicional, pois entendemos ser o embrião congelado considerado nascituro e, assim, sujeito de direito subordinado a condição, uma vez que só será de fato sujeito de seus direitos ao ser implantado no útero materno e nascer com vida. Deve, portanto, desde então ter seus interesses defendidos.

Por isso, no que diz respeito ao denominado embrião préimplantatório, fica evidente a necessidade de legislação que o proteja expressamente.

\footnotetext{
${ }^{64}$ Neste sentido: DIAS, Maria Berenice. Manual das Sucessões. São Paulo: Revista dos Tribunais, 2008. p. 326.

${ }^{65}$ BITTAR, Carlos Alberto. O direito de família e a Constituição de 1988. In. O nascituro no Código Civil e no nosso direito constituendo. São Paulo: Saraiva, 1989. p. 40.

${ }^{66}$ Ibid. p. 40.
} 


\subsection{A DIFERENÇA ENTRE REPRODUÇÃO HUMANA ASSISTIDA POST MORTEM E A IMPLANTAÇÃo DE EMBRIÕES CONGELAdOS POST MORTEM E OS EFEITOS DESTAS NA VOCAÇÃO HEREDITÁRIA.}

Neste momento, é importante estabelecer a diferença entre duas situações, as quais estamos analisando neste trabalho, que, para muitos podem parecer idênticas, mas que para o direito são completamente distintas. Seus efeitos jurídicos são bastante diferentes, principalmente no que diz respeito ao direito de filiação e ao direito sucessório.

Ao utilizarmos as expressões "reprodução humana assistida" ou “concepção post mortem", estamos nos referindo àquela situação na qual o procedimento (um dos quatro procedimentos de técnicas reprodutivas já analisados: fertilização in vitro - FIVETE; transferência intrafalopiana de zigoto - ZIFT; inseminação intra uterina - IIU; ou transferência intrafalopiana de gametas - GIFT) é realizado após a morte do genitor. Ou seja, o sêmen (material reprodutivo masculino) do genitor é congelado e, após sua morte, o procedimento de reprodução assistida é realizado.

Já na “implantação de embriões congelados post mortem”, o que ocorre é o procedimento de fertilização em laboratório (fertilização in vitro - FIVETE ou transferência intrafalopiana de zigoto - ZIFT) antes da morte do genitor. O casal, por algum motivo, em geral por dificuldade de engravidar ou em função de alguma doença, resolve fazer tratamento de fertilidade. Um grande número de embriões é produzido e somente alguns são implantados, sendo os demais congelados. Muitas vezes o que acontece é a morte do genitor antes da implantação dos embriões e a mulher prossegue com o procedimento.

Portanto, as situações são distintas e geram conseqüências e efeitos jurídicos também distintos, uma vez que o primeiro caso envolve o congelamento tão somente de espermatozóides do genitor (material genético masculino), enquanto que, no segundo caso, há o congelamento de 
embriões já concebidos em laboratório (material genético masculino fertilizado ao material genético feminino). O que gera a importante questão já analisada de serem considerados como nascituros e, assim, sujeitos de direito, ou, simplesmente, como prole eventual, para os efeitos da sucessão.

Quando o Código Civil trata da vocação hereditária, no artigo 1.798 (como já vimos), em tese, exclui o concebido após a morte do autor da herança, mediante inseminação artificial, sem que tenha havido prévia concepção, a participar da sucessão de seu pai. Mas, como já vimos também, há defensores de serem os embriões congelados herdeiros necessários, estando, portanto, incluídos na participação da herança de seu pai, tese a qual nos filiamos.

No caso de técnica conceptiva post mortem ainda sequer há embrião no momento da abertura da sucessão do cônjuge ou companheiro. E para a compreensão da vocação hereditária e sua interpretação de acordo com o artigo 1.798, do Código Civil, é importante levar-se em consideração a simultaneidade da existência do herdeiro concebido e do autor da sucessão. ${ }^{67}$

Como visto, as novas técnicas de reprodução assistida possibilitam a ocorrência de filiação biológica após a morte do autor da sucessão, de maneira que se o homem tiver conservado material genético (esperma) poderá possibilitar a utilização pela mulher ou companheira do mesmo após o seu falecimento. ${ }^{68}$

No Brasil, não temos legislação proibitiva da implantação ou técnica conceptiva post mortem, como acontece na Alemanha e Suécia, tampouco existe lei admitindo tal prática. Na França, a concepção post mortem é proibida e o consentimento externado em vida perde o efeito, mas há uma

\footnotetext{
${ }^{67}$ HIRONAKA, Giselda Maria Fernandes Novaes. Comentários ao Código Civil - parte especial: do direito das sucessões. v.XX. $2^{\mathrm{a}}$ Ed. São Paulo: Saraiva, 2003. p. 87.

${ }^{68}$ FILHO, Carlos Cavalcanti de Albuquerque. Fecundação Artificial post mortem e o Direito Sucessório. In: PEREIRA, Rodrigo da Cunha. Anais do V Congresso de direito de Família. Disponível em <www.ibdfam.com.br>. Acesso em 13 mar. 2008.
} 
proposta legislativa que pretende reconhecer a capacidade sucessória da

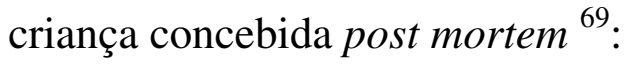

"Para suceder, é necessário existir no momento da abertura da sucessão, salvo nos casos de inseminação post mortem quando o marido defunto expressou inequivocamente a sua vontade, por ato notarial e sob a condição que a inseminação tenha sido feita nos 180 dias após a sua morte". ${ }^{70}$

O autor Carlos Cavalcanti de Albuquerque Filho defende com muita precisão serem os embriões excedentários sujeitos de direito. O autor entende que a problemática acerca da concepção post mortem não se estende à situação da implantação de embriões excedentários após a morte do genitor. Isto porque no momento da morte (abertura da sucessão) já existe embrião, ou seja, já há concepção no momento da morte do autor da herança e, portanto, tem o indivíduo vocação para herdar.

Para a autora Giselda Hironaka podem ser herdeiros legítimos, testamentários ou mesmo legatários, os indivíduos que já tiverem nascido no momento da abertura da sucessão (morte do autor da herança), bem como todos que já estivessem concebidos no mesmo momento. ${ }^{71}$

Seguindo-se ainda a orientação de Albuquerque Filho, ao se outorgar personalidade jurídica ao embrião in vitro, estamos pretendendo caracterizá-lo como sujeito de direito. Sendo assim, tal qual o nascituro, é o embrião pré-implantatório titular de direitos subordinados à condição. E tal condição é suspensiva (implantação no útero) ou resolutiva (não implantação). ${ }^{72}$

Há na jurisprudência atual poucos casos envolvendo tais situações. E esses poucos casos dos quais temos notícia são todos internacionais.

\footnotetext{
${ }^{69}$ Ibid.

${ }^{70}$ Ibid.

${ }^{71}$ HIRONAKA, Giselda Maria Fernandes Novaes. Comentários ao Código Civil - parte especial: do direito das sucessões. v.XX. $2^{\text {a }}$ Ed. São Paulo: Saraiva, 2003. p. 86.

${ }^{72}$ MEIRELLES, Jussara Maria Leal de. Os Embriões Humanos Mantidos em Laboratório e a proteção da pessoa: o novo Código Civil Brasileiro e o texto Constitucional. In: Novos temas de Biodireito e Bioética. Coord. Heloisa Helena Barbosa et al. Rio de Janeiro: Renovar, 2000.
} 
Um caso internacional notório envolvendo reprodução assistida post mortem é o célebre leading case Parpalaix, ocorrido na França na década de 1980. Em agosto de 1981, Corine Richard encontrou o amor no jovem Alain Parpallaix, passando a morar juntos. Poucas semanas depois da união surgiram sintomas de câncer nos testículos de Alain que, antes de submeterse à quimioterapia, que o ameaçava com a esterilidade, optou em depositar seu esperma numa clínica de conservação de sêmen, para uso futuro. Corine e Alain casaram-se in extremis, mas dois dias depois da cerimônia, ele faleceu; alguns meses depois Corine compareceu à clínica para ser inseminada com os gametas de seu finado esposo, mas os responsáveis pela empresa recusaram o pedido, por falta de previsão legal.

A jovem bateu às portas do Tribunal de Créteil, França, onde se discutiu a titularidade das células e a existência de um contrato de depósito que obrigaria o centro a restituir o esperma, alegando os médicos que não se cuidava de pacto de entrega, na medida em que o material da pessoa morta é uma coisa fora do comércio e no território francês não havia lei que autorizasse a fecundação póstuma.

Depois de longo debate, a decisão do Tribunal condenou a clínica a devolver à viúva o sêmen reclamado, impondo uma cláusula penal por eventual demora. Infelizmente a inseminação não teve sucesso, pois os espermatozóides já não mais estavam potencializados para a fecundação. ${ }^{73}$

Outros dois casos no âmbito internacional de extrema importância para o assunto que discutimos, são os leading cases Winley v. Astrue e Evans v. Johnston, os quais tratam da fecundação in vitro e congelamento de embriões para posterior implantação.

Em 6 de outubro de 1990, Amy Finley e Wade Finley Jr. casaram-se no Estado de Arkansas, Estados Unidos. Enquanto estavam casados submeteram-se a um tratamento de fertilidade na University of Arkansas for

\footnotetext{
${ }^{73}$ Situação relatada em: GIORGIS, José Carlos Teixeira. A inseminação póstuma. Disponível em $<$ http://www.espacovital.com.br>. Acesso em 22 jun. 2008.
} 
Medical Sciences (UAMS) e, posteriormente, participaram de um programa de fertilização in vitro e transferência embrionária. Em junho de 2001, os médicos produziram dez embriões a partir dos óvulos de Amy e dos espermatozóides de Wade. Dois dos embriões foram implantados no útero de Amy, quatro embriões foram congelados para preservação e os outros quatro foram descartados. Contudo, Amy sofreu um aborto natural de ambos os embriões.

Em 19 de julho de 2001, Wade morreu e pouco menos de um ano depois, em junho de 2002, Amy submeteu-se à implantação de dois dos embriões previamente congelados, o que resultou na gravidez de uma criança, que nasceu em 4 de março de 2003. Em abril do mesmo ano, Amy entrou com uma ação na justiça pedindo que seu filho fosse beneficiado pelo seguro de saúde de seu pai com subsídio em sua herança.

O pedido foi negado em primeira instância, e um "Juiz Administrativo" (Administrative Law Judge) decidiu, em junho de 2006, por aceitar o pedido. Contudo, a Corte de Apelação (Appeals Concil) reviu a decisão e negou o pedido de Amy. Ela então recorreu, sob o argumento de que a concepção havia ocorrido no momento da fertilização in vitro e que não havia lei que proibisse que uma criança concebida através de métodos artificiais herdasse de seu pai. No entanto, seu pedido foi novamente negado. ${ }^{74}$

Na Inglaterra, em 2001, ao descobrir que sofria de câncer de ovário, Natallie Evans e seu noivo Howard Johnston decidiram submeter-se a um procedimento de fecundação in vitro para que os embriões fossem congelados e, após a remoção dos ovários de Natallie e sua recuperação do câncer, implantados. Para não ficar impossibilitada de ter filhos biológicos antes da cirurgia de remoção dos ovários, Natallie foi a uma clínica especializada e seis dos seus óvulos foram fertilizados com seis espermatozóides de Howard. Natallie até cogitou congelar somente alguns

\footnotetext{
${ }^{74}$ Disponível em: <Courts.arkansas.gov/opinions/2008a/20080110/07-627.pdf>. Acesso em 11 ago. 2008.
} 
de seus óvulos, mas Howard a convenceu de congelar somente os embriões, uma vez que desejavam ter filhos juntos. Os embriões foram então congelados, mas meses depois, em 2002, o casal se separou.

Curada do câncer, Natallie queria prosseguir com o tratamento: implantar um embrião e ter um filho, mas Howard não concordou, pois já não desejava ter filhos com sua ex-noiva. Para a lei britânica, deve haver o consentimento de ambos os genitores para que a implantação seja feita. A moça então se socorreu na justiça britânica e na justiça européia e, em 10 de abril de 2007, a Corte Européia de Direitos Humanos (CEDH) recusou o pedido de restituição dos embriões congelados à Natallie e ela não pode mais ter filhos. ${ }^{75}$

Nos três casos, se mostram claramente distintas as situações que envolvem concepção post mortem, das que envolvem implantação embrionária post mortem.

Como visto, muitas questões surgem diante de casos tão complexos que somente passaram a ser possíveis com o surgimento e o desenvolvimento da biotecnologia. No Brasil, não se tem notícia de casos acerca da implantação embrionária ou concepção póstumas relacionadas ao direito sucessório. Desta forma, se faz necessária a busca de casos estrangeiros para que possamos discutir a aplicação da legislação brasileira nestas situações.

\footnotetext{
75 Disponível em: <http://noticias.uol.com.br/ultnot/afp/2007/04/10/ult1806u5852.jhtm>. Acesso em 12 ago. 2008.
} 


\section{Capítulo iv \\ Princípios Constitucionals}

\subsection{Princípio da Dignidade da Pessoa humana}

"Kant, o "filósofo da dignidade", certamente não imaginava que as suas idéias originais de dignidade ocupariam o centro e seriam o veio condutor das constituições democráticas do final do século XX e as do século XXI. Essas noções de dignidade incorporaram-se de tal forma ao discurso jurídico que se tornou impensável qualquer julgamento ou hermenêutica sem a consideração dos elementos que compõem e dão dignidade ao humano. Seguindo a tendência personalista do Direito Civil, o Direito de Família assumiu como seu núcleo axiológico a pessoa humana e como seu cerne a dignidade humana. Isso significa que todos os institutos jurídicos deverão ser interpretados à luz desse princípio, funcionalizando a família à plenitude da realização da dignidade e da personalidade de cada um de seus membros. A família perdeu, assim, o seu papel primordial de instituição, ou seja, o objeto perdeu sua primazia para o sujeito. Seu verdadeiro sentido apenas se perfaz se vinculada, de forma indelével, à concretização da dignidade das pessoas que a compõem, independente do modelo que assumiu, dada sua realidade plural na contemporaneidade." 76

Em se tratando de reprodução humana assistida, não podemos perder de vista um dos princípios básicos do direito: o da dignidade da pessoa humana, consagrado no texto da Constituição Federal, em seu art. $1^{\circ}$, III, o qual sempre deverá servir de base para a utilização de qualquer das técnicas de reprodução artificial.

As novas situações geradas pelo avanço da biotecnologia no campo da genética precisam ser corretamente dimensionadas, ética e legalmente, para que a dignidade da pessoa humana, princípio básico do Estado Democrático de Direito, possa ser resguardada em todos os processos artificiais de reprodução. ${ }^{77}$

\footnotetext{
${ }^{76}$ PEREIRA, Rodrigo da Cunha. Apresentação ao II Congresso Brasileiro de Direito de Família. In: Anais do II Congresso Brasileiro de Direito de Família. Disponível em <www.ibdfam.com.br>. Acesso em 15 jun. 2008.

${ }^{77}$ FERNANDES, Silvia da Cunha. As Técnicas de Reprodução Humana Assistida e a Necessidade de sua Regulamentação Jurídica. Rio de Janeiro: Renovar, 2005. p. 6.
} 
O respeito à dignidade da pessoa humana, essência de todo o ordenamento jurídico, deve ser visto como paradigma pilar do biodireito. A pessoa humana e sua dignidade constituem o principal fundamento da sociedade e do Estado, sendo o princípio que deverá prevalecer sobre qualquer tipo de avanço biotecnológico. Desta forma, não pode o biodireito admitir qualquer comportamento que venha a reduzir a pessoa humana à qualidade de coisa, retirando dela sua dignidade. ${ }^{78}$

Assim assinala a autora Maria Helena Diniz:

"Os direitos humanos, decorrentes da condição humana e das necessidades fundamentais de toda pessoa humana, referem-se à preservação da integridade e da dignidade dos seres humanos e à plena realização de sua personalidade." 79

$\mathrm{O}$ respeito à dignidade da pessoa humana tornou-se um comando jurídico no Brasil com o advento da Constituição Federal de 1988. Após mais de duas décadas de ditadura sob o regime militar, a Constituição explicitou a dignidade da pessoa humana como um dos fundamentos da República. Isto significa dizer que o valor da dignidade alcança todos os setores da ordem jurídica. ${ }^{80}$

O fundamento material da dignidade pode ser desdobrado em quatro postulados: o sujeito moral reconhece a existência dos outros como sujeitos iguais a ele; merecedores do mesmo respeito à integridade psicofísica de que é titular; é dotado de vontade livre; e é parte do grupo social. E são base da dignidade os princípios jurídicos da igualdade, da integridade psicofísica, da liberdade e da solidariedade. ${ }^{81}$

Portanto, o fundamento jurídico da dignidade humana manifesta-se, em primeiro lugar, no princípio da igualdade, ou seja, no direito de não

\footnotetext{
${ }^{78}$ DINIZ, Maria Helena. O Estado Atual do Biodireito. São Paulo: Saraiva, 2007. p. 17.

${ }^{79}$ Ibid. p. 19.

${ }^{80}$ MORAES, Maria Celina Bodin de. Danos à Pessoa Humana: uma leitura civil-constitucional dos danos morais. Rio de Janeiro: Renovar, 2003. p. 82-128.

${ }^{81}$ Ibid.
} 
receber tratamento discriminatório, no direito de ter direitos iguais aos demais. Esta é conhecida como igualdade formal, segunda a qual "todos são iguais perante a lei”. Há também a igualdade substancial, cuja medida prevê a necessidade de tratar as pessoas, quando desiguais, de forma desigual. $^{82}$

No princípio de proteção à integridade psicofísica da pessoa estão incluídos apenas o direito de não ser torturado e o de ser titular de garantias penais, tradicionalmente. No âmbito civil, contudo, a integridade psicofísica garante diversos direitos da personalidade (vida, nome, imagem, honra, etc.). No princípio está contido ainda o direito à existência digna.

Segundo a professora Maria Celina Bodin de Moraes:

“Atualmente, as maiores perplexidades em torno do tema dizem respeito ao extraordinário desenvolvimento da biotecnologia e a suas conseqüências sobre a esfera psicofísica do ser humano. Assim, por exemplo, no âmbito do que começa a se configurar como um novo ramo, o do "biodireito", ainda sem regulamentação jurídica adequada, estão problemas decorrentes da reprodução assistida - como a procriação post-mortem e o congelamento de embriões -, da privacidade dos dados genéticos, da experimentação em seres humanos, dos atos de disposição sobre o próprio corpo, da mudança de sexo, acontecimentos plenamente factíveis desde a aquisição, cada vez mais veloz, das tecnologias necessárias." 83 (grifos nossos)

A necessidade de regular os dilemas criados pelo desenvolvimento da biotecnologia encontrou um legislador despreparado para oferecer respostas efetivas. Isto porque a elaboração de uma ordem jurídica que regule fatos sociais novos implica a definição de princípios que possam servir de parâmetros para a sua normatização. ${ }^{84}$

Por sua vez, o princípio da liberdade individual se embasa numa perspectiva de privacidade, de intimidade, de exercício da vida privada. Liberdade significa, hoje, poder realizar, sem interferências de qualquer

\footnotetext{
82 Ibid

83 Ibid.

${ }^{84}$ Ibid.
} 
gênero, as próprias escolhas individuais, exercendo-as como melhor convier. No entanto, a liberdade deve ser regulada em prol da solidariedade social. ${ }^{85}$

E, por fim, o princípio da solidariedade, proclamado pela Constituição Federal em seu artigo $3^{\circ}$, como um dos objetivos da República, é salientado também pela professora Bodin de Moraes:

"Se a solidariedade fática decorre da necessidade imprescindivel da coexistência humana, a solidariedade como valor deriva da consciência racional dos interesses em comum, interesses esses que implicam, para cada membro, a obrigação moral de "não fazer aos outros o que não se deseja que lhe seja feito." 86

Do ponto de vista jurídico, o princípio constitucional da solidariedade é constituído pelo conjunto de instrumentos voltados a garantir uma existência digna, em uma sociedade livre e justa, sem excluídos ou marginalizados. ${ }^{87}$

Neste contexto, devemos enquadrar os nossos questionamentos ao princípio pilar da dignidade da pessoa humana. Em primeiro lugar, deve-se fazer o cotejo do princípio à situação do espermatozóide congelado.

A criança, fruto de concepção realizada com material genético de seu pai morto, deve ser protegida constitucionalmente, com base no princípio da dignidade da pessoa humana, uma vez que o não reconhecimento dessa filiação fere o principio, no que diz respeito à integridade psicofísica da criança. Ou seja, mesmo não havendo autorização expressa por parte do genitor, essa criança terá sua paternidade reconhecida com base no princípio da dignidade da pessoa humana.

Não se pode, contudo, enquadrá-la no artigo 1.798 do Código Civil, para determinar que seja herdeira necessária de seu pai, mesmo sendo sua

\footnotetext{
${ }^{85}$ Ibid.

${ }^{86}$ Ibid.

${ }^{87}$ Ibid.
} 
descendente direta, tendo em vista que não era sequer concebida ao tempo da morte de seu pai e somente os filhos nascidos ou já concebidos ao tempo da abertura da sucessão pedem ser herdeiros legítimos necessários.

Pode, entretanto, para não contrariar o princípio da igualdade integrante da dignidade da pessoa humana, esta criança, fruto de concepção post mortem, ser considerada como prole eventual, se assim previu o testador em testamento, passando esta criança a ser herdeiro somente testamentário. Mas isso fere o princípio da igualdade entre os filhos, questão esta que veremos mais a frente.

Em segundo lugar, deve-se fazer o cotejo do princípio com a situação dos embriões congelados. A criança, fruto de implantação embrionária após a morte de seu pai, deve, da mesma forma, ser protegida constitucionalmente com base no princípio da dignidade da pessoa humana.

Ou seja, a conclusão é a mesma do caso de congelamento de espermatozóide, qual seja, mesmo não havendo autorização expressa por parte do genitor para a implantação de seus embriões, essa criança terá sua paternidade reconhecida com base no princípio da dignidade da pessoa humana.

Pode-se, ainda, em nossa opinião, ao contrário do primeiro caso, enquadrá-la no artigo 1.798 do Código Civil, para determinar que seja herdeira necessária de seu pai, tendo em vista que já era concebida ao tempo da morte de seu genitor, e, desta forma, sujeito de direitos (subordinados à condição de serem implantados e nascerem com vida), até mesmo do direito de suceder.

\subsection{Direito À FiliaçÃo e o Melhor Interesse da CriançA}

Não há como questionar que o estado de filiação representa um dos elementos da personalidade humana, por integrar um dos aspectos da 
identidade pessoal, comprovando, além da sua existência jurídica, o vínculo de parentesco gerador do poder familiar, e ainda, por demonstrar a provável e desejada verdade afetiva entre pais e filhos. Portanto, a relação paterno/materno-filial encontra-se protegida. ${ }^{88}$

No que diz respeito ao estado de filiação, é a relação de parentesco que se estabelece entre duas pessoas, na qual uma é considerada filha da outra (pai ou mãe). O estado de filiação é a qualificação jurídica dessa relação de parentesco, conferida a alguém, compreendendo uma pluralidade de direitos e deveres reciprocamente considerados. O filho é titular do estado de filiação, da mesma forma que o pai e a mãe são titulares dos estados de paternidade e de maternidade, em relação a ele. ${ }^{89}$

No direito brasileiro, fundado no art. 227 da Constituição e nos artigos 1.593, 1.596 e 1.597 do Código Civil ${ }^{90}$, consideram-se estados de filiação ope legis: a) filiação biológica em face de ambos os pais, havida de relação de casamento ou da união estável, ou em face do único pai ou mãe biológicos, na família monoparental; b) filiação não-biológica em face de ambos os pais, oriunda de adoção regular, ou em face do pai ou da mãe que adotou exclusivamente o filho; e c) filiação não-biológica em face do pai que autorizou a inseminação artificial heteróloga. ${ }^{91}$

\footnotetext{
${ }^{88}$ NETTO, Roberta de Freitas. Uma nova lei: uma guarda planejada em prol do melhor interesse da criança e do adolescente. Disponível em <www.ibdfam.com.br>. Acesso em 26 set. 2008.

89 LÔBO, Paulo Luiz Netto. Direito ao estado de filiação e direito à origem genética: uma distinção necessária. Disponível em <www.ibdfam.com.br>. Acesso em 27 set. 2008.

90 Art. 1.593. O parentesco é natural ou civil, conforme resulte de consangüinidade ou outra origem.

Art. 1.596. Os filhos, havidos ou não da relação de casamento, ou por adoção, terão os mesmos direitos e qualificações, proibidas quaisquer designações discriminatórias relativas à filiação.

Art. 1.597. Presumem-se concebidos na constância do casamento os filhos:

I - nascidos cento e oitenta dias, pelo menos, depois de estabelecida a convivência conjugal;

II - nascidos nos trezentos dias subseqüentes à dissolução da sociedade conjugal, por morte, separação judicial, nulidade e anulação do casamento;

III - havidos por fecundação artificial homóloga, mesmo que falecido o marido;

IV - havidos, a qualquer tempo, quando se tratar de embriões excedentários, decorrentes de concepção artificial homóloga;

$\mathrm{V}$ - havidos por inseminação artificial heteróloga, desde que tenha prévia autorização do marido.

${ }^{91}$ LÔBO, Paulo Luiz Netto. Direito ao estado de filiação e direito à origem genética: uma distinção necessária. Disponível em <www.ibdfam.com.br>. Acesso em 27 set. 2008.
} 
Nessas situações, a convivência familiar e a afetividade são presumidas, ainda que de fato não ocorram. Mas, de qualquer forma, a convivência familiar e a afetividade constroem e consolidam o estado de filiação.

Encontram-se na Constituição Brasileira vários fundamentos do estado de filiação: a) todos os filhos são iguais, independentemente de sua origem (art. 227, $\S 6^{\circ}$ ); b) a adoção, como escolha afetiva, alçou-se integralmente ao plano da igualdade de direitos (art. $227, \S \S 5^{\circ}$ e $6^{\circ}$ ); c) a comunidade formada por qualquer dos pais e seus descendentes, incluindose os adotivos, tem a mesma dignidade de família constitucionalmente protegida (art. $226, \S 4^{\circ}$ ); não é relevante a origem ou existência de outro pai (genitor); d) o direito à convivência familiar, e não à origem genética, constitui prioridade absoluta da criança e o do adolescente (art. 227, caput); e) impõe-se a todos os membros da família o dever de solidariedade, uns com os outros, dos pais para os filhos, dos filhos para os pais (arts. 229 e $\left.230{ }^{92}\right) .{ }^{93}$

Desta forma, podemos concluir que o direito à filiação é um direito garantido constitucionalmente, não devendo este ser excepcionado. Toda e qualquer criança tem direito à filiação e ao reconhecimento de sua paternidade, mesmo tendo o seu pai (ou mãe) já falecido ao tempo de seu nascimento, de sua implantação no útero da mãe ou até mesmo de sua concepção. O não reconhecimento da filiação fere, em primeiro plano, o princípio da dignidade da pessoa humana, no que diz respeito à integridade psicofísica da criança.

No que concerne ao estado de filiação, se faz necessário exaltar ainda que, além de estabelecer a Constituição Federal, em seu art. 227

\footnotetext{
92 Art. 229. Os pais têm o dever de assistir, criar e educar os filhos menores, e os filhos maiores têm o dever de ajudar e amparar os pais na velhice, carência ou enfermidade.

Art. 230. A família, a sociedade e o Estado têm o dever de amparar as pessoas idosas, assegurando sua participação na comunidade, defendendo sua dignidade e bem-estar e garantindo-lhes o direito à vida.

93 LÔBO, Paulo Luiz Netto. Direito ao estado de filiação e direito à origem genética: uma distinção necessária. Disponível em <www.ibdfam.com.br>. Acesso em 27 set. 2008.
} 
caput, a absoluta primazia dos direitos da criança e do adolescente, a Convenção Internacional dos Direitos da Criança, da ONU, de 1989, passou a integrar o direito brasileiro interno desde 1990. O art. $3.1^{94}$ da Convenção estabelece que todas as ações relativas aos menores devem considerar, primordialmente, "o interesse maior da criança" 95. Por força da convenção, deve ser garantida uma ampla proteção ao menor, no sentido de fortalecimento de sua situação jurídica, atribuindo aos pais, conjuntamente, a tarefa de cuidar da educação e do desenvolvimento.

O princípio do melhor interesse da criança não é uma recomendação ética, mas um mandamento determinante nas relações da criança e do adolescente com seus pais, com sua família, com a sociedade e com o Estado. A aplicação da lei deve sempre atentar para o princípio, consagrado, segundo Luiz Edson Fachin, como critério significativo na decisão e na aplicação da lei, tutelando-se os filhos como seres prioritários ${ }^{96}$. O princípio está consagrado nos artigos $4^{\circ}$ e $6^{\circ}$ da Lei n. 8.069, de 1990 (Estatuto da Criança e do Adolescente). ${ }^{97}$

Os princípios básicos da Convenção Internacional sobre os Direito da Criança foram introduzidos no texto constitucional de 1988, sendo o artigo 277, de nossa Lei Maior, reconhecido na comunidade internacional como a síntese da Convenção ${ }^{98}$.

\footnotetext{
943.1 - Todas as ações relativas às crianças, levadas a efeito por autoridades administrativas ou órgãos legislativos, devem considerar, primordialmente, o interesse maior da criança.

${ }^{95}$ LÔBO, Paulo Luiz Netto. Direito ao Estado de Filiação e Direito à Origem Genética: uma distinção necessária. Disponível em <www.ibdfam.com.br>. Acesso em 27 set. 2008.

96 FACHIN, Luiz Edson. Da Paternidade: relação biológica e afetiva. Disponível em <www.ibdfam.com.br>. Acesso em 13 mai. 2008. p. 125.

${ }^{97}$ Art. $4^{\circ}$ É dever da família, da comunidade, da sociedade em geral e do poder público assegurar, com absoluta prioridade, a efetivação dos direitos referentes à vida, à saúde, à alimentação, à educação, ao esporte, ao lazer, à profissionalização, à cultura, à dignidade, ao respeito, à liberdade e à convivência familiar e comunitária.

Art. $6^{\circ} \mathrm{Na}$ interpretação desta Lei levar-se-ão em conta os fins sociais a que ela se dirige, as exigências do bem comum, os direitos e deveres individuais e coletivos, e a condição peculiar da criança e do adolescente como pessoas em desenvolvimento.

${ }^{98}$ BARBOZA, Heloisa Helena. O princípio do melhor interesse da criança e do adolescente. In: Anais do XX Congresso de Direito de Família. Disponível em <www.ibdfam.com.br $>$. Acesso em 8 set. 2008 .
} 
O Estatuto da Criança e do Adolescente concretizou e expressou os novos direitos desta parte da população, que explicita o valor intrínseco da criança como ser humano e a necessidade de respeito à sua condição de pessoa em desenvolvimento. A adoção da doutrina da proteção integral veio afirmar o princípio do melhor interesse da criança, já existente em nossa legislação e que encontra suas raízes na Declaração Universal dos Direitos da Criança. ${ }^{99}$

Com o advento da Constituição Federal de 1988, o critério interpretativo, sintetizado na fórmula anglo-saxônica the best interest of the child, adquiriu, entre nós, conteúdo normativo específico pela cláusula geral de tutela da pessoa humana introduzida pelo artigo $1^{\circ}$, inciso III, da Constituição Federal de 1988 e determinado especialmente pela Lei $8.069 / 90$, em seus artigos $4^{\circ}$ e $6^{\circ}$.

A Constituição Federal de 1988, ao estabelecer uma nova ordem jurídica, introduziu a “constitucionalização do Direito Civil”, promovendo profundas mudanças, em especial no Direito de Família, a começar pelo reconhecimento de outras entidades familiares que não o casamento, que perdeu o lugar até então ocupado de personagem principal do Direito de Família. Nesse sentido, afirma Edson Luiz Fachin ${ }^{100}$, que, após a Constituição, o Código Civil perdeu o papel de lei fundamental do Direito de Família, sendo certo, no tocante às relações pais e filhos, que o Estatuto da Criança e do Adolescente (Lei 8.069/90) assumiu tal lugar, dando execução às linhas estruturais fixadas pela Lei Maior.

Desta forma, a incorporação da importância da proteção integral no corpo constitucional explicitou o princípio do melhor interesse da criança, aplicável a toda criança e adolescente. Em consequiência, a partir de 1988, tal doutrina e princípio passaram a reger, necessariamente, as relações familiares que envolvam criança e adolescente.

\footnotetext{
99 Ibid.

100 FACHIN, Luiz Edson. Da paternidade, relação biológica e afetiva. Disponível em <www.ibdfam.com.br>. Acesso em 13 mai. 2008.
} 
Foram diretamente atingidos os institutos da filiação, do pátrio poder, da guarda, do estabelecimento da paternidade, da adoção e da tutela. Impõem-se os novos princípios sobre os dispositivos existentes, quer no Código Civil, quer em leis extravagantes, derrogando-os em todos os termos incompatíveis com a nova ordem. ${ }^{101}$

É consolidada, desse modo, a base estrutural dos direitos que têm como titular a criança e o adolescente, na qualidade de pessoas em desenvolvimento, e que têm assegurado, como prioridade absoluta, o seu melhor interesse. Outrossim, é indispensável que se faça uma nova leitura dos acima mencionados institutos, a começar pela filiação, considerando-se derrogado qualquer dispositivo que seja incompatível com os princípios da plena igualdade entre os filhos ou do melhor interesse da criança e do adolescente. $^{102}$

\subsection{PrincíPIO da lgualdade ENTRE OS FILHOS}

Em nosso sistema jurídico o princípio da igualdade entre os filhos é consagrado constitucionalmente, independentemente da situação jurídica dos pais, de acordo com o artigo 227, $\S 6^{\circ}$, da Constituição Federal. Desta maneira não se pode admitir a possibilidade de haver legislação infraconstitucional ou decisão judicial restritivas de direito do filho gerado mediante concepção post mortem, e, muito menos, do filho havido por implantação embrionária post mortem. Tais situações não encontram respaldo constitucional, uma vez que a Constituição Federal não previu qualquer exceção ao princípio da igualdade entre os filhos, não cabendo ao

\footnotetext{
101 Ibid.

${ }^{102}$ BARBOZA, Heloisa Helena. O Estatuto da Criança e do Adolescente e a disciplina da filiação no Código Civil. In: $O$ melhor interesse da criança: um debate interdisciplinar. Rio de Janeiro: Renovar, 1999. p. 113-115.
} 
legislador infraconstitucional, e muito menos ao intérprete da lei estabelecer exceções ao princípio.

Desta forma, podemos concluir que o princípio constitucional da igualdade entre os filhos atua em socorro às situações em questão. Portanto, a igualdade entre os filhos deve ser levada em consideração sempre que nos depararmos com a situação do filho concebido ou implantado após a morte de seu genitor. Sendo assim, o princípio age a favor do concebido ou implantado após o falecimento do autor da sucessão, uma vez que qualquer saída restritiva em desfavor do mesmo resultaria em discriminação atentatória à igualdade com os demais filhos, seus irmãos biológicos. ${ }^{103}$

O artigo 1.596 do Código Civil ${ }^{104}$ prevê que os filhos, havidos ou não da relação do casamento, ou havidos por adoção, terão os mesmos direitos e qualificações entre si, proibidas quaisquer designações discriminatórias relativas à filiação.

Há, contudo, uma exceção ao princípio da isonomia: os filhos havidos na constância do casamento gozam da presunção de paternidade, "pater is est quem justae nuptiae demonstrant", ou seja, pai é aquele que demonstra justas núpcias. Logo, a única hipótese em que a mulher, sem a presença do pai, pode registrar o filho em nome daquele é se ela comprovar o casamento.

O Código Civil de 2002, em seu artigo $1.597^{105}$, previu as situações em que se presume a paternidade. Esta regulamentação tão acanhada encontra como justificativa não estar o tema suficientemente amadurecido,

\footnotetext{
${ }^{103}$ FILHO, Carlos Cavalcanti de Albuquerque. Fecundação Artificial post mortem e o Direito Sucessório. In: PEREIRA, Rodrigo da Cunha. Anais do V Congresso de direito de Família. Disponível em <www.ibdfam.com.br>. Acesso em 13 mar. 2008.

${ }^{104}$ Art. 1.596. Os filhos, havidos ou não da relação de casamento, ou por adoção, terão os mesmos direitos e qualificações, proibidas quaisquer designações discriminatórias relativas à filiação.

${ }^{105}$ Art. 1.597. Presumem-se concebidos na constância do casamento os filhos:

I - nascidos cento e oitenta dias, pelo menos, depois de estabelecida a convivência conjugal;

II - nascidos nos trezentos dias subseqüentes à dissolução da sociedade conjugal, por morte, separação judicial, nulidade e anulação do casamento;

III - havidos por fecundação artificial homóloga, mesmo que falecido o marido;

IV - havidos, a qualquer tempo, quando se tratar de embriões excedentários, decorrentes de concepção artificial homóloga;

V - havidos por inseminação artificial heteróloga, desde que tenha prévia autorização do marido.
} 
trazendo problemas altamente técnicos, que ficariam melhor solucionados em lei especial. ${ }^{106}$

Portanto, levando em consideração o princípio da igualdade entre os filhos e o que prevê o Código Civil, os filhos havidos por concepção assistida ou implantação embrionária post mortem são presumidamente concebidos na constância do casamento para fins de reconhecimento de paternidade.

Sendo assim, com base no princípio da igualdade entre os filhos, não podem ser estes excluídos da sucessão de seu pai, mesmo havendo a previsão do artigo 1.798 do Código Civil. ${ }^{107}$

Cabe esclarecer que nesse ponto o Código foi contraditório. Isto porque prevê que se presumem concebidos na constância do casamento os filhos havidos por fecundação artificial homóloga, mesmo que falecido o marido e os filhos havidos, quando se tratar de embriões excedentários, de concepção artificial homóloga. Prevê também que os filhos havidos na constância do casamento gozam da presunção de paternidade. Entretanto, ao tratar da vocação hereditária, o Código se contradiz ao excluir da sucessão os filhos havidos por técnica reprodutiva homóloga após a morte do marido por não serem estes concebidos no momento da abertura da sucessão.

Deve, portanto, o intérprete da lei, ao se deparar com tal contradição, encontrar subsídios nos princípios constitucionais, para encontrar a resposta mais coerente e justa, que são, neste caso, o princípio da dignidade da pessoa humana e o princípio da igualdade entre os filhos. Desta forma, com base nesses princípios constitucionais, deve-se entender que todo e qualquer filho tem direito à paternidade e a suceder em caso de morte de seu pai antes de sua implantação no útero materno e até mesmo no caso sua

\footnotetext{
106 DIAS, Maria Berenice. Manual de Direito das Famílias. $4^{\mathrm{a}}$ Ed. São Paulo: Revista dos Tribunais. 2007. p. 328

107 Art. 1.798. Legitimam-se a suceder as pessoas nascidas ou já concebidas no momento da abertura da sucessão.
} 
concepção post mortem, mesmo que o genitor não tenha deixado autorização para tal prática por escrito.

Cabe esclarecer, contudo, que esta interpretação não autoriza ou estimula tais práticas sem a autorização do genitor. Entretanto, deparandonos com tais situações devemos nos voltar primeiramente para os interesses e direitos da criança, desconsiderando a vontade do pai (que já está morto).

É importante esclarecer que a nossa defesa é a de que só se realizem esses procedimentos com a autorização expressa do genitor, devendo o Estado regulamentar normas impositivas destinadas às clínicas de reprodução humana assistida para que estas só procedam com essas práticas com tal autorização, para evitar futuros conflitos.

Portanto, somente na hipótese de ter havido expressa autorização do homem é que a inseminação de seus espermatozóides ou a implantação embrionária devem ser permitidas após o seu falecimento. O princípio da autonomia da vontade condiciona a utilização do material genético ao consentimento expresso a esse fim. Sem tal autorização, os embriões e os espermatozóides devem ser eliminados, pois não se pode exigir que a clínica entregue à mulher o material genético que se encontra armazenado para que seja nela inseminado, por não se tratar de bem objeto de herança. $^{108}$

108 DIAS, Maria Berenice. Manual de Direito das Famílias. 4 ${ }^{\mathrm{a}}$ Ed. São Paulo: Revista dos Tribunais. 2007. p. 330. 


\section{Capítulo V}

\section{Presunção da paternidade na reprodução assistida HOMÓLOGA, AINDA QUE MORTO O GENITOR}

\subsection{CONSIDERAÇÕES ACERCA dA FILIAÇÃo}

Apesar do que se ouve muito, a entidade familiar não está em decadência. Pelo contrário, a família é o resultado das transformações sociais. Houve a reorganização das relações familiares em busca do atendimento aos interesses mais valiosos das pessoas humanas: afeto, solidariedade, lealdade, confiança, respeito e amor. ${ }^{109}$

Tendo dissipado seus fundamentos tradicionais, a família reencontrou-se com alicerce na afetividade e na solidariedade. Os vínculos de afeto e de solidariedade resultam da convivência familiar e não necessariamente do sangue. Como esclarece Eduardo de Oliveira Leite, as indagações doutrinárias mais recentes têm insistido, de forma cada vez mais freqüente e firme, que a filiação não é somente fundada sobre os laços de sangue; o vínculo sanguíneo determina, para a grande maioria dos pais, um laço fundado sobre a vontade da aceitação dos filhos. Logo, a vontade individual é a seqüência ou o complemento necessário do vínculo biológico. ${ }^{110}$

Como já vimos, filiação é a relação de parentesco que se estabelece entre duas pessoas, uma das quais é considerada filha da outra. $\mathrm{O}$ estado de filiação é a qualificação jurídica dessa relação de parentesco, atribuída a alguém, compreendendo um complexo de direitos e deveres reciprocamente considerados.

\footnotetext{
109 DIAS, Maria Berenice. Manual de Direito das Famílias. 4ª Ed. São Paulo: Revista dos Tribunais. 2007. p. 34

${ }^{110}$ LEITE, Eduardo de Oliveira. Procriações artificiais e o direito: aspectos médicos, religiosos, psicológicos e jurídicos. São Paulo: Revista dos Tribunais, 1995. p. 203.
} 
O estado de filiação constitui-se por força de lei ou em razão da posse de estado, por força da convivência familiar. No direito brasileiro atual, com fundamento nos artigos 1.596 e 1.597 do Código Civil ${ }^{111}$, como também já foi visto, consideram-se estados de filiação:

a) a filiação biológica em face de ambos os pais, havida de relação de casamento ou união estável, ou em face de um único pai ou mãe biológicos, na família monoparental;

b) a filiação não biológica em face de ambos os pais, oriunda de adoção regular; ou em face do único pai ou da mãe que adotou exclusivamente o filho; e

c) a filiação não-biológica em face do pai que autorizou a inseminação artificial heteróloga.

Nas três hipóteses, a convivência familiar e a afetividade são presumidas, ainda que na realidade não ocorram.

\subsection{Aplicação da Regra do ART. 1.597, Incisos III E VI, do Código CIVIL, À CONCEPÇÃO E À IMPLANTAÇÃO EMBRIONÁRIA PÓSTUMAS}

A já citada Resolução do Conselho Federal de Medicina nº 1.358/92, que dispõe sobre Reprodução Humana Artificial, adota normas éticas para a utilização das técnicas de reprodução assistida como dispositivo deontológico a ser seguido pelos médicos. Estabelece que as clínicas,

\footnotetext{
${ }^{111}$ Art. 1.596. Os filhos, havidos ou não da relação de casamento, ou por adoção, terão os mesmos direitos e qualificações, proibidas quaisquer designações discriminatórias relativas à filiação. Art. 1.597. Presumem-se concebidos na constância do casamento os filhos:

I - nascidos cento e oitenta dias, pelo menos, depois de estabelecida a convivência conjugal;

II - nascidos nos trezentos dias subseqüentes à dissolução da sociedade conjugal, por morte, separação judicial, nulidade e anulação do casamento;

III - havidos por fecundação artificial homóloga, mesmo que falecido o marido;

IV - havidos, a qualquer tempo, quando se tratar de embriões excedentários, decorrentes de concepção artificial homóloga;

V - havidos por inseminação artificial heteróloga, desde que tenha prévia autorização do marido.
} 
centros ou serviços podem criopreservar espermatozóides, óvulos e préembriões. Mas, além disso, no momento da criopreservação, cônjuges ou companheiros devem expressar sua vontade, por escrito, quanto ao destino que será dado aos pré-embriões criopreservados, em caso de divórcio, doenças graves ou de falecimento de um deles ou de ambos, e quando desejam doá-los. Tal previsão deveria estar imposta por lei, pela relevância de sua observância.

O que vimos na jurisprudência internacional ${ }^{112}$ é que ocorre, a nosso ver, uma interpretação equivocada das situações envolvendo concebidos e implantados após o falecimento do genitor, uma vez que se observam em primeiro plano os interesses de terceiros e os interesses dos herdeiros existentes até o momento, ignorando-se o direito do cônjuge sobrevivente e, mais importante, o direito da criança envolvida nessas peculiares situações.

Em nosso ordenamento jurídico não existe a possibilidade de não reconhecimento de filiação e não é o fato de um dos genitores estar morto que vai afastar a priori o direito do nascido, mediante concepção ou implantação embrionária póstuma, de ter em sua certidão de nascimento o nome dos pais, embora um deles já esteja morto, mesmo que não tenha havido expressa autorização pelo genitor para a realização do procedimento post mortem. ${ }^{113}$

O direito à reprodução é reconhecido como direito fundamental e, como ressalta Eduardo de Oliveira Leite:

"Assim como a vida sexual do casal é comum a ambos, e depende da anuência, ou animus de cada cônjuge, da mesma forma, diante da esterilidade, a decisão de procriar artificialmente depende de um desejo comum, que determina o projeto parental. (...) o recurso à procriação artificial não deita suas raízes no

\footnotetext{
112 leading cases Parpalaix, Winley v. Astrue e Evans v. Johnston, já citados no texto.

113 FILHO, Carlos Cavalcanti de Albuquerque. Fecundação Artificial post mortem e o Direito Sucessório. In: PEREIRA, Rodrigo da Cunha. Anais do V Congresso de direito de Família. Disponível em <www.ibdfam.com.br>. Acesso em 13 mar. 2008.
} 
puro egoísmo mas é, antes de tudo, resultado de um projeto parental tendente a contornar problemas oriundos de um handicap de ordem natural". ${ }^{114}$

Não se admite, contudo, que a deliberação de ter um filho tenha sido inicialmente manifestada e, por circunstância imprevista, como, por exemplo, uma morte prematura, possa esse projeto não ser materializado após o falecimento do cônjuge ou companheiro. $\mathrm{O}$ avanço da biomedicina permite que o intuito de ter um filho possa se materializar após a morte de um dos cônjuges ou companheiros.

O Código Civil de 2002 tratou da presunção de paternidade em seu artigo 1.597 e os incisos III e IV dispõem:

“Art. 1.597. Presumem-se concebidos na constância do casamento os filhos:

III - Havidos por fecundação artificial homóloga, mesmo que falecido o marido; IV - Havidos, a qualquer tempo, quando se tratar de embriões excedentários, decorrentes de concepção artificial homóloga.

(...)."

A concepção e a implantação de embriões post mortem, das quais tratamos, são técnicas de reprodução humana assistida homólogas, uma vez que o material genético utilizado é fornecido pelo próprio casal que pretende ter o filho. Contudo, nesses casos, para alguns doutrinadores, surgem dúvidas com relação à filiação, visto que a mulher será inseminada com os gametas de seu marido ou companheiro, ou será implantada com os embriões do casal, após a morte do genitor.

Apesar desta visão equivocada, entendemos que a criança gerada através da concepção assistida, mesmo que falecido o genitor, tem direito à presunção da filiação, uma vez que é considerada concebida na constância

\footnotetext{
${ }^{114}$ GAMA, Guilherme Calmon Nogueira da. A nova Filiação: o biodireito e as relações parentais. Rio de Janeiro: Renovar, 2003. p. 709.
} 
do casamento por fecundação artificial homóloga, nos termos do artigo 1.597, inciso III, do Código Civil.

E a criança gerada através da implantação de embriões após a morte do genitor não se encaixaria no inciso III do artigo 1.597, mas em seu inciso IV. E, desta forma, a criança fruto de implantação de embriões após a morte do genitor tem a paternidade presumida por força do inciso IV do artigo 1.597 do Código Civil.

Em ambos os casos, a autorização expressa para a realização do procedimento seria necessária, mas mesmo que não observada essa exigência de autorização expressa do genitor falecido, a criança tem direito à paternidade presumida por força do artigo 1.597, incisos III e IV.

A presunção tradicional, contida no inciso II do artigo 1.597, atribui a paternidade ao marido da mãe em relação ao filho nascido dentro dos 300 dias após sua morte. A fertilização artificial pode ocorrer depois de transcorridos os 300 dias, persistindo a presunção da paternidade, desde que seja utilizado o gameta do marido ou que sejam aqueles embriões frutos de seus gametas.

O autor Paulo Luiz Netto Lobo, contudo, faz uma ressalva:

"O princípio da autonomia dos sujeitos, como um dos fundamentos do biodireito, condiciona a utilização do material genético do falecido ao consentimento expresso que tenha deixado para esse fim. Assim, não poderá a viúva exigir que a clínica de reprodução assistida lhe entregue o sêmen armazenado para que seja nela inseminado, por não ser objeto de herança. A paternidade deve ser consentida, porque não perde a dimensão da liberdade" 115

Nesta posição, é importante lembrar também que durante a I Jornada de Direito Civil aprovou-se os seguintes enunciados ${ }^{116}$ :

\footnotetext{
${ }^{115}$ LOBO, Paulo Luiz Netto. Código Civil Comentado: direito de família. Relações de parentesco. Direito patrimonial. v. XVI. Artigos 1.591 a 1.693. Coord. Álvaro Vilaça Azevedo. São Paulo: Atlas, 2003. p. 51.

${ }^{116}$ Disponível em <www.tj.rj.gov.br>. Acesso em 5 jun. 2008.
} 
Enunciado n. 106 - Art. 1.597, inc. III: para que seja presumida a paternidade do marido falecido, será obrigatório que a mulher, ao se submeter a uma das técnicas de reprodução assistida com o material genético do falecido, esteja na condição de viúva, sendo obrigatório, ainda, que haja autorização escrita do marido para que se utilize seu material genético após sua morte.

Enunciado n. 107 - Art. 1.597, IV: finda a sociedade conjugal, na forma do art. 1.571, a regra do inc. IV somente poderá ser aplicada se houver autorização prévia, por escrito, dos ex-cônjuges para a utilização dos embriões excedentários, só podendo ser revogada até o início do procedimento de implantação desses embriões.

Entretanto, a utilização não consentida do sêmen ou embrião deve ser melhor analisada, uma vez que não existe a possibilidade de a criança não ter sua paternidade reconhecida, mesmo que o genitor não tenha autorizado expressamente o procedimento.

Entendemos ser necessária a autorização expressa do genitor que veio a falecer para que a concepção ou implantação embrionária sejam realizadas. Contudo, caso seja o procedimento efetivado mesmo sem a autorização do genitor pré-morto (por descuido ou negligência da clínica de reprodução humana assistida), não há como essa criança fruto da concepção ou implantação não autorizada não ter a sua paternidade reconhecida, por força do que expõe o artigo 1.597, incisos III e IV do Código Civil.

E, se são presumidamente concebidos na constância do casamento os havidos por fecundação artificial homóloga, mesmo que falecido o marido e os havidos, quando se tratar de embriões excedentários, a qualquer tempo, têm esses filhos reconhecidos seus direitos sucessórios com base no que dispõe o artigo 1.798 do Código Civil. Mas desse ponto trataremos melhor mais adiante.

Cabe ressaltar ainda que embora para a maioria dos autores a presunção do artigo 1.597 do Código Civil diga respeito apenas ao casamento, não abrangendo a união estável, a posição que mais nos agrada 
é a que defende que o artigo se estende à união estável, no que diz respeito à presunção da paternidade. ${ }^{117}$

${ }^{117}$ FILHO, Carlos Cavalcanti de Albuquerque. Fecundação Artificial post mortem e o Direito Sucessório. In: PEREIRA, Rodrigo da Cunha. Anais do V Congresso de direito de Família. Disponível em <www.ibdfam.com.br>. Acesso em 13 mar. 2008. 


\section{Capítulo VI \\ Os Efeitos da Concepção e dA ImplantaçÃo de Embriões \\ Congelados APÓS A MORTE do GENITOR nOS DiReitos de FAMÍLIA E DAS SUCESSÕES}

\subsection{Uma SoluçÃo a Favor da Criança}

O Código Civil atual preferiu não cuidar de questões relacionadas à reprodução humana assistida, e o próprio professor Miguel Reale ${ }^{118}$ afirmou sempre que um dos objetivos da sua proposta de codificação era precisamente a de não regulamentar assuntos que ultrapassassem as fronteiras da área civil, ou que abordassem problemas de alta especificidade técnica. O legislador brasileiro preferiu deixar a cargo da lei específica a disciplina dos diversos pontos de discussão, com relação à reprodução humana assistida, sobretudo na sua relação com o direito das sucessões, ponto que aqui mais nos interessa.

Enquanto a legislação especial não é promulgada, as questões fundamentais devem ser tratadas com base nos entendimentos doutrinários, e através dos métodos interpretativos dos dispositivos que tratam destas questões. E por este caminho vamos seguir, através de uma interpretação civil constitucional, tentando encontrar uma solução que tenha por fundamentos os princípios previstos pela Constituição Federal que balizam a interpretação jurídica, tendo em vista, em primeiro plano, os princípios da dignidade da pessoa humana, o melhor interesse da criança e a igualdade entre os filhos.

A respeito de ter o embrião pré-implantatório vocação hereditária e poder ter direito à sucessão de seus genitores biológicos, para nós a questão

\footnotetext{
${ }^{118}$ REALE, Miguel. História do Novo Código Civil - Col. Biblioteca de Direito Civil - Vol. 1. São Paulo: Revista dos Tribunais, 2005. p. 35.
} 
não traz tantos problemas, uma vez que parte da doutrina ${ }^{119}$ que define que o conceito tradicional de nascituro - ser concebido e ainda não nascido ampliou-se e hoje vai além dos limites da concepção in vivo (no ventre feminino), sendo possível também a concepção in vitro.

E, a nosso ver, o nascituro agora permanece como sendo o ser concebido, embora ainda não nascido, mas sem que faça qualquer diferença o local da concepção. O conceito de nascituro, a nosso ver e de acordo com o entendimento da magistrada Maria Berenice Dias ${ }^{120}$, tem semelhança, portanto, com o conceito de embrião. De forma que ainda que não implantado, o embrião está concebido e, desde que identificado com os doadores dos gametas, terá direito à herança, assim como o nascituro, uma vez que o artigo 1.798 do Código Civil admite estarem legitimados a suceder não apenas as pessoas nascidas, mas também aquelas concebidas ao tempo da abertura da sucessão.

O que estamos discutindo no presente trabalho, portanto, é se o embrião, fecundado no laboratório, e aguardando, in vitro, a implantação no ventre materno, já é entendido como sujeito de direito. Ou seja, tem o embrião ainda não implantado, chamado de pré-implantatório, direito de personalidade e direito à sucessão?

A lei, ao falar em "pessoa já concebida”, não distingue o local da concepção e não impõe que esteja implantado no ventre materno. O que a lei exige é apenas e tão-somente a concepção. No entanto, há autores ${ }^{121}$ que afirmam não haver possibilidade de se deixar de reconhecer que a concepção a ser protegida é aquela em que o embrião concebido já se encontra implantado no aparelho reprodutor da mãe. Somente a partir desse instante passariam a ser resguardados seus direitos potenciais de nascituro. Como nascituro significa “o que há de nascer” e o embrião excedentário, sem a implantação, não tem qualquer possibilidade de nascer, não seria

\footnotetext{
${ }^{119}$ DIAS, Maria Berenice. Manual das sucessões. São Paulo: Revista dos Tribunais, 2008. p. 326. ${ }^{120}$ Ibid. p. 326.

${ }^{121}$ Neste sentido: HIRONAKA, Giselda Maria Fernandes Novaes. As inovações biotecnológicas e o direito das sucessões. Retirado do site <www.ibdfam.org.br>. Acesso em 10 jul. 2008.
} 
razoável considerá-lo como nascituro antes da transferência para o útero materno.

No entanto, outros autores ${ }^{122}$ entendem ser os embriões préimplantatórios sujeitos de direito, subordinados à condição de serem implantados e nascerem com vida, por já se encontrarem concebidos, não importando o local da concepção. Têm, portanto, eles vocação hereditária e direito à paternidade. Neste sentido, foi aprovado o seguinte enunciado na III Jornada de Direito Civil:

Enunciado n. 267 - A regra do art. 1.798 do Código Civil deve ser estendida aos embriões formados mediante o uso de técnicas de reprodução assistida, abrangendo, assim, a vocação hereditária da pessoa humana a nascer cujos efeitos patrimoniais se submetem às regras previstas para a petição da herança.

Para esses autores o embrião implantado após a morte de seu genitor tem direito à herança, sendo ele herdeiro legítimo e necessário. E esse direito, como já vimos, está subordinado à condição de ser o embrião implantado e de nascer a criança com vida para se efetivar.

Outra questão, contudo, seria a de saber se, uma vez concebida uma criança após a morte do pai biológico, por concepção post mortem, teria ela direito a sucedê-lo. O problema se resume na questão de se viabilizar um suposto direito sucessório a uma pessoa que, no momento da abertura da sucessão, não era sequer concebida. Sabemos que material genético pode ser mantido congelado por algum tempo, nas clínicas de reprodução assistida e ser utilizado após a morte do pai.

Esta possibilidade parece admitida pelo inciso III do artigo 1.597 do Código Civil, mas seguramente envolve direito da personalidade do pai,

\footnotetext{
${ }^{122}$ Neste sentido: DIAS, Maria Berenice. Manual das sucessões. São Paulo: Revista dos Tribunais, 2008. p.326. e FILHO, Carlos Cavalcanti de Albuquerque. Fecundação Artificial post mortem e o Direito Sucessório. In: PEREIRA, Rodrigo da Cunha. Anais do V Congresso de direito de Família. Disponível em <www.ibdfam.com.br>. Acesso em 13 mar. 2008.
} 
doador do sêmen. O caput do artigo admite uma presunção de paternidade que deve ser analisada com cuidado, uma vez que não se pode presumir que alguém quisesse ser pai depois de sua morte, salvo se houvesse manifestação clara da vontade neste sentido, isto é, autorizando a concepção post mortem.

O inciso III não faz ressalva acerca da manifestação do pai, contudo, o problema foi resolvido na I Jornada de Direito Civil do Centro de Estudos Judiciários, por meio do enunciado n. 106, como já expomos, que ressalta:

Enunciado n. 106 - Art. 1.597, inc. III: para que seja presumida a paternidade do marido falecido, será obrigatório que a mulher, ao se submeter a uma das técnicas de reprodução assistida com material genético do marido, esteja na condição de viúva, sendo obrigatório, ainda, que haja autorização escrita do marido para que se utilize seu material genético após a sua morte. (grifos nossos)

Então, supondo que tenha havido autorização do pai pré-morto e que os demais requisitos tenham sido observados, admite-se a concepção post mortem, operando-se o vínculo parental de filiação, com todas as consequiências resultantes, em atenção à Constituição Federal, em seu artigo $226, \S 6^{\circ}$, incluindo os direitos sucessórios relativamente à herança do pai falecido. ${ }^{123}$

Existem duas correntes que dividem os doutrinadores no sentido de saber se a vontade de ter filhos deve ser protegida para além da morte ${ }^{124}$. $\mathrm{O}$ primeiro grupo de autores defende essa proteção sob o argumento de ser convergente do direito da criança à existência. A outra posição apóia a impossibilidade da técnica de concepção póstuma como forma de assegurar o direito do filho a uma estrutura familiar formada por ambos os pais. ${ }^{125}$ Para a corrente restritiva, mesmo que haja o consentimento prévio do

\footnotetext{
${ }^{123}$ HIRONAKA, Giselda Maria Fernandes Novaes. As inovações biotecnológicas e o direito das sucessões. Retirado do site <www.ibdfam.org.br>. Acesso em 10 jul. 2008.

${ }_{124}^{124}$ AGUIAR, Mônica. Direito à filiação e bioética. Rio de Janeiro: Forense, 2005. p. 117.

${ }^{125}$ Ibid. p. 117.
} 
genitor pré-morto à criopreservação do sêmen e óvulo para a concepção post mortem, a morte funciona como causa revogadora da permissão ao emprego da técnica médica.

E, quanto aos efeitos da concepção post mortem, existem três correntes doutrinárias:

A primeira não reconhece qualquer direito ao filho gerado após a morte do genitor, mediante procedimento de reprodução humana assistida, quer no âmbito do direito de família, quer no âmbito do direito sucessório. Além disso, os defensores desta corrente entendem que há proibição para realização de tal prática, como acontece em países como a Alemanha e Suécia, que adotam sistemas positivos restritivos, em que se proíbem e sancionam essas atuações, consideradas socialmente danosas. ${ }^{126}$

Para Mônica Aguiar, mesmo que tenha ocorrido a concepção post mortem com a autorização do genitor pré-morto, a morte opera como revogação do consentimento prestado e, portanto, o concebido será filho apenas do cônjuge sobrevivente ${ }^{127}$.

No mesmo sentido Jesualdo Eduardo de Almeida Júnior afirma que o embrião fecundado post mortem não teria direito sucessório algum, pois não é pessoa concebida e muito menos pessoa nascida, não se enquadrando na regra contida no artigo 1.798 , do Código Civil. ${ }^{128}$

A segunda posição, relativamente excludente, admite efeitos diminuídos, no direito de família, sem, no entanto, reconhecer à criança gerada, nessas especiais circunstâncias, a condição de herdeiro do genitor pré-morto. A esse respeito Guilherme Calmon pondera que se eventualmente tal técnica for empregada, a paternidade poderá ser estabelecida com base no fundamento biológico e sob o pressuposto do

\footnotetext{
${ }^{126}$ FILHO, Carlos Cavalcanti de Albuquerque. Fecundação Artificial post mortem e o Direito Sucessório. In: PEREIRA, Rodrigo da Cunha. Anais do V Congresso de direito de Família. Disponível em <www.ibdfam.com.br>. Acesso em 13 mar. 2008.

${ }_{127}$ AGUIAR, Mônica. Direito à filiação e bioética. Rio de Janeiro: Forense, 2005. p. 117.

128 JUNIOR, Jesualdo Eduardo de Almeida. Técnicas de reprodução assistida e o biodireito. Disponível em <http://www.jusnavigandi.com.br>. Acesso em 10 jul. 2008.
} 
risco, mas não para fins de direitos sucessórios, o que pode conduzir a criança prejudicada a pleitear a reparação dos danos materiais que sofrer de sua mãe e dos profissionais que a auxiliaram a procriar utilizando-se do sêmen de cônjuge ou companheiro já falecido, com fundamento na responsabilidade civil. ${ }^{129}$

Em ataque a esta posição, expõe o autor Carlos Cavalcanti de Albuquerque Filho:

"A tese da responsabilização civil da genitora da criança por se haver submetido à técnica de inseminação após a morte do cônjuge ou companheiro, utilizando material genético deste, não deve prevalecer porque se assim fosse os filhos de relações eventuais, não planejadas, não programadas e muitas vezes indesejadas, teriam os mesmos ou mais direitos para responsabilizar os genitores. No caso da inseminação post mortem o filho é desejado, querido, muitas vezes fez parte de um projeto parental que não se concretizou por circunstâncias alheias à vontade dos interessados. A perspectiva excludente vai de encontro aos modernos princípios do direito de família, especialmente aos princípios da igualdade de filiação, da afetividade e da dignidade da pessoa humana. É Importante ressaltar que alguns autores defendem a possibilidade de inserção do concebido após a morte do autor da herança apenas no âmbito da sucessão testamentária, quando houver expressa disposição de última vontade em favor de prole eventual do próprio de cujus." 130

Nesse sentido tem-se a observação de Guilherme Calmon, que ressalta que alguns autores têm sustentado que a parte final do artigo 1.718, do Código de 1916, admitia a disposição testamentária em favor de prole eventual própria quando o testador, prevendo a possibilidade de vir a falecer antes da concepção da criança, confecciona seu testamento referindo à prole dele próprio. No Código Civil de 2002, o artigo 1.799, inciso I, admite o chamamento, na sucessão testamentária, dos filhos ainda não

\footnotetext{
${ }^{129}$ GAMA, Guilherme Calmon Nogueira da. A nova filiação: o biodireito e as relações parentais. Rio de Janeiro: Renovar, 2003. p. 733.

${ }^{130}$ FILHO, Carlos Cavalcanti de Albuquerque. Fecundação Artificial post mortem e o Direito Sucessório. In: PEREIRA, Rodrigo da Cunha. Anais do V Congresso de direito de Família. Disponível em <www.ibdfam.com.br>. Acesso em 13 mar. 2008.
} 
concebidos de pessoas indicadas pelo testador, desde que tais pessoas estejam vivas à época da abertura da sucessão. ${ }^{131}$

Se o testador pode conferir a sua herança à prole eventual de terceiros, também pode, sem qualquer restrição, conferir a sua herança à sua própria prole. É necessário lembrar que seria altamente prejudicial à ordem jurídica a espera indefinida de uma possível prole, tendo em vista que o sêmen pode ficar crioconservado por anos ou décadas e, só após, ser utilizado. Portanto, para essa corrente, deverá ser fixado o prazo de espera do nascimento dos filhos, dentro da própria disposição testamentária, ou mesmo através de uma lei que regule o assunto. ${ }^{132}$

Em sentido contrário, Giselda Hironaka aduz que não poderá indicar sua própria prole eventual, uma vez que a lei exige que a pessoa indicada pelo testador esteja viva no momento da abertura da sucessão. No entanto, admite que o testador poderá fazê-lo por via reflexa: basta que indique a doadora do óvulo, se testador, ou o doador do espermatozóide, se testadora. $^{133}$

A terceira corrente, denominada de inclusiva, à qual nos filiamos, juntamente com Carlos Cavalcanti de Albuquerque Filho, reconhece plenos efeitos à concepção post mortem, admitindo iguais direitos tanto na seara do direito de família como no âmbito das sucessões, à criança concebida mediante essa técnica.

Trata-se, portanto, de uma espécie de concepção homóloga, uma vez que o material genético, sêmen ou óvulo, é de um dos pais, casado ou em união estável, que pretende ter o filho assim gerado.

Biologicamente, portanto, não há qualquer dúvida sobre a paternidade e maternidade e, caso exista, o laboratório ou médico que

\footnotetext{
${ }^{131}$ GAMA, Guilherme Calmon Nogueira da. A nova filiação: o biodireito e as relações parentais. Rio de Janeiro: Renovar, 2003. p. 732.

132 QUEIROZ, Juliane Fernandes. Paternidade: aspectos jurídicos e técnicas de inseminação artificial. Belo Horizonte: Del Rey, 2001. p. 80.

${ }^{133}$ HIRONAKA, Giselda Maria Fernandes Novaes. Comentários ao Código Civil-parte especial: do direito das sucessões. v. XX. $2^{\mathrm{a}}$ Ed. São Paulo: Saraiva, 2003. p. 96.
} 
efetuou a técnica de concepção post mortem poderá esclarecer, inclusive para o efeito de posterior registro da criança nascida. ${ }^{134}$

Não há expressa proibição legal do uso da técnica de concepção post mortem no Brasil ${ }^{135}$, nem tampouco existe legislação que a permita. O que de fato há é a omissão legislativa sobre a matéria em questão.

Outrossim, devemos compreender a extensão acerca deste tema por meio da interpretação jurídica e da analogia. Devemos, portando, atentar para a interpretação do artigo 226 da Constituição Federal, que trata a família como base da sociedade, não fazendo qualquer referência ao tipo ao qual o Estado garante especial proteção. O legislador menciona expressamente, como entidades familiares, o casamento, a união estável e a entidade monoparental. Ou seja, não se pode excluir qualquer entidade na qual estejam presentes os requisitos de afetividade, estabilidade e ostensibilidade. $^{136}$

Além da interpretação da Constituição Federal, podemos também trazer, para ilustrar a discussão, o direito estrangeiro, como já o fizemos, uma vez que esses regramentos de fora podem servir de orientação para o legislador brasileiro. Mas é preciso fazer, antes, uma escolha política para saber se devemos nos ater a reconhecer como entidades familiares somente aquelas inseridas, de modo expresso, no art. 226 da Constituição Federal ou se, ao contrário, devem ser admitidos outros modelos de família. E, ainda, como opção, de poder fixar a existência ou não de um direito à procriação,

\footnotetext{
${ }^{134}$ FILHO, Carlos Cavalcanti de Albuquerque. Fecundação Artificial post mortem e o Direito Sucessório. In: PEREIRA, Rodrigo da Cunha. Anais do V Congresso de direito de Família. Disponível em <www.ibdfam.com.br>. Acesso em 13 mar. 2008.

${ }^{135}$ O Projeto de Lei 90/99 parece excluir a possibilidade da fecundação post mortem. O artigo 15 , $\S 5^{\circ}$, impõe como "obrigatório o descarte de gametas e embriões nos casos conhecidos de falecimento de doadores ou depositantes (inciso V) e no caso de falecimento de pelo menos uma das pessoas que originaram embriões preservados (inciso VI). Em complemento, o artigo 20, prevê que havendo fecundação post mortem, no caso de burla desse dispositivo, "a criança não se beneficia de efeitos patrimoniais e sucessórios em relação ao falecido".

${ }^{136}$ LOBO, Paulo Luiz Netto. Entidades familiares constitucionalizadas: para além do numerus clausus. In: Anais do III Congresso Brasileiro de Direito de Família. Família e cidadania. Coord. Rodrigo da Cunha Pereira. Disponível em <www.ibdfam.com.br>. Acesso em 20 mai. 2008. p. 89
} 
o qual embasaria o emprego das técnicas por pessoa solteira ou por casal homossexual. ${ }^{137}$

Nesse sentido, esclarece Paulo Luiz Netto Lobo:

"Os tipos de entidades familiares explicitados nos parágrafos do art. 226 da Constituição são meramente exemplificativos, sem embargo de serem os mais comuns, por isso mesmo merecendo referência expressa. As demais entidades familiares são tipos implícitos incluídos no âmbito de abrangência do conceito amplo e indeterminado de família indicado no caput. Como todo conceito indeterminado, depende de concretização dos tipos, na experiência da vida, conduzindo à tipicidade aberta, dotada de ductilidade e adaptabilidade" 138

Em conclusão, nos termos do artigo 226, caput, e $\S 7^{\circ}$, da Constituição Federal ${ }^{139}$, o planejamento familiar é de livre decisão do casal, fundado nos princípios da dignidade da pessoa humana e da paternidade responsável.

Desta forma, não se pode negar a possibilidade de a pessoa sozinha ter um projeto parental que atenda perfeitamente aos interesses da criança, o que vem ao encontro do contido na Lei n. 9.263/96, que prevê, no seu artigo $3^{\text {o }}$, caput $^{140}$, que o planejamento familiar é parte integrante de várias ações em prol da mulher, do homem ou do casal, numa perspectiva mais abrangente que a do texto constitucional, mas perfeitamente adequada ao nosso sistema jurídico.

Nos termos da legislação acima mencionada entende-se por planejamento familiar o conjunto de ações de controle da fecundidade que

\footnotetext{
${ }^{137}$ AGUIAR, Mônica. Direito à filiação e bioética. p. 128.

${ }^{138}$ LOBO, Paulo Luiz Netto. Entidades familiares constitucionalizadas: para além do numerus clausus. In: Anais do III Congresso Brasileiro de Direito de Família. Família e cidadania. Coord. Rodrigo da Cunha Pereira. Disponível em <www.ibdfam.com.br>. Acesso em 20 mai. 2008. p. 95. ${ }^{139}$ Art. 226. A família, base da sociedade, tem especial proteção do Estado.

$\$ 7^{\circ}$ Fundado nos princípios da dignidade da pessoa humana e da paternidade responsável, o planejamento familiar é livre decisão do casal, competindo ao Estado propiciar recursos educacionais e científicos para o exercício desse direito, vedada qualquer forma coercitiva por parte de instituições oficiais ou privadas.

${ }^{140}$ Lei n. 9.263/96 - Art. $3^{\circ}$ O planejamento familiar é parte integrante do conjunto de ações de atenção à mulher, ao homem ou ao casal, dentro de uma visão de atendimento global e integral à saúde.
} 
garanta iguais direitos de constituição, limitação ou aumento da prole pela mulher, pelo homem ou pelo casal. ${ }^{141}$

Diante disso, em nosso sistema jurídico, o qual reconhece o pluralismo das entidades familiares e a total liberdade do planejamento familiar, com base nos princípios da dignidade da pessoa humana e da paternidade responsável, não se pode admitir norma ou regra restritiva à concepção post mortem. ${ }^{142}$

Além disso, é perfeitamente admissível que o projeto parental se tenha iniciado em vida, dos cônjuges ou companheiros e venha a se materializar após a morte de um dos mesmos. A evidente manifestação de vontade, fundada no consentimento expresso que tenha deixado o falecido para utilização do material genético deixado para esse fim, legitima e legaliza a concepção post mortem, fazendo com que os efeitos jurídicos sejam reconhecidos, em sua plenitude, à criança nascida mediante a utilização desta técnica.

A criança concebida por concepção post mortem é filha para todos os efeitos jurídicos, a começar pela submissão ao regramento constitucional da igualdade da filiação, previsto no artigo $227, \S 6^{\circ}$, da Constituição Federal, norma que não admite qualquer exceção legal. De maneira que o filho biológico concebido após o falecimento de um dos genitores, mediante técnica de reprodução humana assistida, é parente, da classe dos descendentes, de primeiro grau, do falecido.

O reconhecimento deste filho é presumido, nos termos do artigo 1.597, inciso III, do Código Civil, ao admitir como concebidos na constância do casamento os filhos havidos por fecundação homóloga,

\footnotetext{
${ }^{141}$ LOBO, Paulo Luiz Netto. Código Civil Comentado: direito de família. Relações de parentesco. Direito patrimonial. v. XVI. Artigos 1.591 a 1.693. Coord. Álvaro Vilaça Azevedo. São Paulo: Atlas, 2003. p. 44.

${ }^{142}$ FILHO, Carlos Cavalcanti de Albuquerque. Fecundação Artificial post mortem e o Direito Sucessório. In: PEREIRA, Rodrigo da Cunha. Anais do V Congresso de direito de Família. Disponível em <www.ibdfam.com.br>. Acesso em 13 mar. 2008.
} 
mesmo que falecido o marido. Encontrando-se o cônjuge sobrevivente na condição de viúvo(a) e havendo autorização expressa do outro cônjuge à realização da concepção póstuma não há qualquer dúvida sobre a incidência da presunção estabelecida na legislação civil.

A expressa manifestação de vontade do cônjuge que veio a falecer é imprescindível à realização da concepção post mortem, mas não ao reconhecimento dos efeitos jurídicos quanto à criança nascida com o uso dessa técnica. Ou seja, deve haver a autorização, mas caso tenha sido realizado o procedimento sem a mesma, a criança tem seus direitos garantidos.

Portanto, havendo inequívoca manifestação de vontade do genitor que venha a falecer antes de realizado o procedimento de reprodução assistida admite-se a conclusão do procedimento, uma vez que qualquer solução diversa irá contra o princípio do melhor interesse da criança, a qual tem o direito de ser reconhecida filha do pai falecido para todos os efeitos jurídicos, no âmbito do direito de família e das sucessões.

Nesse mesmo raciocínio, complementa Albuquerque Filho:

"Na hipótese de a inseminação post mortem ser realizada em relação a casal que vive em união estável, para aqueles, como Paulo Lobo, que admitem a aplicabilidade da presunção de filiação, paternidade e maternidade, à união estável, as mesmas conclusões quanto ao casamento valem para o companheirismo." 143

Acrescenta-se a este entendimento que a expressa manifestação da vontade do cônjuge ou companheiro que veio a falecer é imprescindível à realização da concepção post mortem. Contudo, é importante esclarecer que mesmo sendo esta uma imposição e uma condição sine qua non para que o procedimento seja realizado, no caso de haver a concepção póstuma sem

\footnotetext{
${ }^{143}$ FILHO, Carlos Cavalcanti de Albuquerque. Fecundação Artificial post mortem e o Direito Sucessório. In: PEREIRA, Rodrigo da Cunha. Anais do V Congresso de direito de Família. Disponível em <www.ibdfam.com.br>. Acesso em 13 mar. 2008.
} 
essa expressa autorização (por negligência ou erro da clínica de reprodução humana assistida), ainda assim, com base nos princípios já analisados anteriormente, devem ser reconhecidos os direitos à filiação e à sucessão desta criança.

As soluções apontadas por alguns doutrinadores ${ }^{144}$ quanto ao reconhecimento de efeitos diminuídos ao nascido mediante inseminação póstuma no âmbito do direito de família, excluídas as relações sucessórias, contrariam completamente o princípio constitucional da igualdade de filiação, uma vez que o legislador constitucional não previu qualquer exceção ao princípio da igualdade entre os filhos, independentemente da situação em que se encontrem os pais, não cabendo ao intérprete, mesmo em hipóteses não previstas expressamente pelo legislador, estabelecer restrições. A Constituição Federal não faz distinção entre os filhos, qualquer que seja sua origem ou o tipo de relação mantida por seus genitores. ${ }^{145}$

Ao discursar sobre o princípio da igualdade entre os filhos, o autor Paulo Lôbo esclarece que não se permite que a interpretação das normas relativas à filiação possa revelar qualquer resíduo de desigualdade de tratamento aos filhos, independentemente de sua origem, desaparecendo os efeitos jurídicos diferenciados nas relações pessoais e patrimoniais entre pais e filhos, entre irmãos e no que concerne aos laços de parentesco. ${ }^{146}$

Ainda segundo este posicionamento, quando o legislador tratou do tema acerca da concepção póstuma, no artigo 1.798, do Código Civil, quis beneficiar o embrião ainda não concebido.

\footnotetext{
${ }^{144}$ Neste sentido: GAMA, Guilherme Calmon Nogueira da. A nova filiação: o biodireito e as relações parentais. Rio de Janeiro: Renovar, 2003. P. 733.

${ }^{145}$ HIRONAKA, Giselda Maria Fernandes Novaes. Comentários ao Código Civil - parte especial: do direito das sucessões. v. XX. $2^{\mathrm{a}}$ Ed. São Paulo: Saraiva, 2003. p. 93.

${ }^{146}$ LOBO, Paulo Luiz Netto. Código Civil Comentado: direito de família. Relações de parentesco. Direito patrimonial. v. XVI. Artigos 1.591 a 1.693. Coord. Álvaro Vilaça Azevedo. São Paulo: Atlas, 2003. p. 40.
} 
Quando a lei garante o vínculo de filiação, não se justifica privar o filho de legitimação para ter direito à herança. ${ }^{147}$ Desta forma, os efeitos sucessórios da concepção post mortem são amplos, não se restringindo somente à sucessão testamentária como entendem alguns autores, que defendem que podendo o testador chamar a suceder, por testamento, a prole eventual de terceiros, nos termos do artigo 1.799, inciso I, do Código Civil, poderia, igualmente, beneficiar a sua própria prole eventual.

Portanto, a possibilidade da exclusão de direitos àquele concebido e gerado mediante técnica reprodutiva post mortem e àquele fruto de implantação embrionária póstuma, viola os princípios da dignidade humana, do melhor interesse da criança, e da igualdade entre os filhos. E, segundo a lição de Emmanuel Kant ${ }^{148}$, dignidade é tudo aquilo que não tem um preço, seja pecuniário seja estimativo, ou seja, o que é inestimável, indisponível. O reconhecimento de amplos direitos à criança nascida mediante concepção ou implantação póstumas respeita a Constituição Federal à medida que o legislador se preocupou com a dignidade das pessoas e a proteção à família dá-se nas pessoas de cada um dos que a integram. $^{149}$

Com relação aos direitos sucessórios, é essencial atentar para os princípios que fundamentam a transmissão da herança. A vocação hereditária é regulada pela lei vigente ao tempo da abertura da sucessão e o filho concebido tem direito à sucessão, sendo impossível afastar-se o direito à herança em se tratando de concepção decorrente de técnica de reprodução humana assistida, seja ela quando for.

Não compartilhamos da posição a qual defende que os não concebidos ao tempo da morte do genitor, só terão direito sucessório na

\footnotetext{
${ }^{147}$ ALMEIDA, José Luiz Gavião de. Código civil comentado. Direitos das sucessões. Sucessão em geral. Sucessão legítima - artigos 1.784 a 1.856. v. XVIII. São Paulo: Atlas, 2003. p. 104.

${ }_{148}$ KANT, Immanuel. Fundamentação da metafísica dos costumes. São Paulo: Martin Claret, 1990. p. 77.

${ }^{149}$ FILHO, Carlos Cavalcanti de Albuquerque. Fecundação Artificial post mortem e o Direito Sucessório. In: PEREIRA, Rodrigo da Cunha. Anais do V Congresso de direito de Família. Disponível em <www.ibdfam.com.br>. Acesso em 13 mar. 2008.
} 
hipótese de ter o pai, fornecedor do sêmen, expressamente manifestado seu consentimento para que a fertilização ocorresse depois de sua morte.

Entendemos, desta forma, que mesmo sem a expressa manifestação do pai, o filho terá direito sucessório não por se tratar da vontade do testador para depois de sua morte, mas sim por constituir um direito garantido expressamente pelo Código Civil, em seu artigo 1.829 , inciso I. ${ }^{150}$

Por fim, cabe ressaltar que no Brasil a legislação infraconstitucional não proíbe a implantação embrionária e a concepção post mortem e a Constituição Federal consagra a igualdade entre os filhos, a dignidade da pessoa humana e o melhor interesse da criança. Não se pode, portanto, admitir qualquer legislação infraconstitucional restritiva do direito do filho assim concebido.

\subsection{A Questão do Prazo para a Utilização do Material Genético Preservado}

Existe ainda uma questão relevante acerca do assunto: o prazo para utilização, pelo cônjuge ou companheiro sobrevivente, do material genético preservado, seja dos embriões, seja dos gametas congelados. A não-fixação de prazo para prole eventual do autor da sucessão surgida por concepção ou implantação embrionária post mortem acarretaria a possibilidade da utilização da ação de petição de herança pela criança gerada na reprodução humana assistida, sendo que os seus efeitos patrimoniais se submeteriam ao prazo previsto para prescrição aquisitiva, aludida pelo artigo 205 do Código Civil. ${ }^{151}$

\footnotetext{
${ }^{150}$ Art. 1.829. A sucessão legítima defere-se na ordem seguinte:

I - aos descendentes, em concorrência com o cônjuge sobrevivente, salvo se casado este com o falecido no regime da comunhão universal, ou no da separação obrigatória de bens (art. 1.640, parágrafo único); ou se, no regime da comunhão parcial, o autor da herança não houver deixado bens particulares

${ }^{151}$ Art. 205. A prescrição ocorre em 10 (dez) anos, quando a lei não lhe haja fixado prazo menor.
} 
O sêmen (diferente do embrião pré-implantatório que só tem potencial para permanecer congelado por três anos) pode ser congelado por anos ou décadas e, só após, ser utilizado. Isso, no entanto, seria altamente prejudicial à ordem e à certeza jurídica, uma vez que haveria uma espera indefinida de uma eventual prole ${ }^{152}$.

Desta forma, caberia ao autor da sucessão, quando manifestar a sua vontade por documento escrito ou por testamento, indicar o prazo de espera do nascimento dos filhos, o qual não deve ultrapassar os dois anos previstos para concepção da prole eventual de terceiro. Ou, não havendo prazo previamente estabelecido, aplicar-se-ia, por analogia, o prazo constante do artigo 1.800, $\S 4^{\circ}$, do Código Civil, ou seja, de dois anos a contar da abertura da sucessão.

\subsection{Projetos de Lel sobre Reprodução Assistida ${ }^{153}$}

Como já foi explicitado ao longo deste trabalho, não existe no Brasil uma legislação infraconstitucional específica que trate da reprodução humana assistida. A Resolução CFM n. 1.358/92 do Conselho Federal de Medicina (já mencionada anteriormente), que, a partir da adoção de normas éticas pelos profissionais da área médica, disciplina a utilização das técnicas reprodutivas, não se assemelha a disposições com força de lei.

Em março de 2002, tramitavam no Congresso Nacional três projetos de lei sobre reprodução humana assistida. O primeiro (PL n. $3.638^{154}$ ), de 29 de março de 1993, instituía normas para a utilização das técnicas de reprodução humana assistida, incluindo as questões relativas à fertilização

\footnotetext{
${ }^{152}$ QUEIROZ, Juliane Fernandes. Paternidade: aspectos jurídicos e técnicas de inseminação artificial. Belo Horizonte: Del Rey, 2001. p. 80.

${ }_{153}$ Informações retiradas de: FERNANDES, Silvia da Cunha. As Técnicas de Reprodução Humana Assistida e a Necessidade de sua Regulamentação Jurídica. Rio de Janeiro: Renovar, 2005. p. 117-125.

${ }^{154} \mathrm{~A}$ íntegra deste projeto encontra-se no Anexo II a esta obra.
} 
in vitro, inseminação artificial e gestação de substituição. $\mathrm{O}$ projeto, contudo, foi arquivado sem aprovação.

O segundo (PL n. $2.855^{155}$ ), datado de 13 de março de 1997, dispunha sobre as técnicas de reprodução humana assistida e dava outras providências. Foi apensado a este projeto, o Projeto de Lei n. 4.665, de 18 de maio de 2001, que dispunha sobre a autorização da fertilização humana in vitro para os casais comprovadamente incapazes de gerar filhos pelo processo natural.

E o terceiro projeto (PLS n. $90^{156}$ ), de 9 de março de 1999, dispunha sobre a reprodução assistida relativamente a seus princípios gerais, mas também foi arquivado sem aprovação.

Todos os três projetos, bem como a Resolução CFM n. 1.358/92, dispõem sobre a aplicação das técnicas de reprodução assistida e determinam que a utilização das técnicas deve se restringir ao auxílio na resolução de problemas de infertilidade.

Relativamente ao consentimento informado, todos os projetos prevêem ser este obrigatório para os pacientes e doadores, o que para nosso tema é de extrema importância, uma vez que diante de qualquer procedimento de reprodução humana assistida, seria obrigatório o termo de consentimento informado, constando a determinação da destinação do material genético em caso de morte dos envolvidos no projeto parental.

A concepção post mortem é considerada crime pelo PLS n. 90/99, obrigando o descarte de gametas em caso de falecimento do doador; no PL n. 2.855/97 impõe-se que o casal determine o destino do material conservado em caso de morte do doador; e a Resolução CFM n. 1.318/92, bem como o PL n. 3.638/93, não proíbem nem permitem expressamente esse tipo de concepção, mas, pelos princípios gerais, condiciona-a ao consentimento em vida.

\footnotetext{
${ }^{155}$ A íntegra deste projeto encontra-se no Anexo III a esta obra.

${ }^{156}$ A íntegra deste projeto encontra-se no Anexo IV a esta obra.
} 
Portanto, podemos perceber que esses projetos de lei deixavam muito a desejar, divergindo, inclusive, em alguns pontos com o Código Civil de 2002.

Em 3 de junho de 2003, foi apresentado ao Congresso Nacional o PL n. $1.184^{157}$, de autoria do Senado Federal, que dispõe sobre a reprodução assistida, definindo normas para a realização de inseminação artificial e fertilização in vitro. Em 13 de fevereiro de 2004, a Comissão de Constituição e Justiça e de Cidadania (CCJC) designou o relator do projeto, que devolveu o projeto para a CCJC sem manifestação.

Este projeto parece mais estruturado e adequado à realidade que os demais. No instrumento particular de consentimento livre e esclarecido deverão constar as condições em que o doador autoriza a utilização de seus gametas, inclusive postumamente.

Contudo, infelizmente, apesar da evolução em relação à propositura de uma legislação infraconstitucional que regule a utilização das técnicas de reprodução assistida, ainda falta embasamento técnico e humano para se tratar dessas questões.

Os projetos de lei estão muito longe de resolver as questões mais intrincadas relacionadas ao tema, principalmente, para nós, no que diz respeito à utilização das técnicas postumamente.

Ao se pretender legislar sobre reprodução assistida, deve-se, antes de qualquer coisa, partir de princípios éticos e constitucionais básicos de respeito à dignidade da pessoa humana, bem como dos princípios gerais de direito universalmente consagrados.

A autora Silvia da Cunha Fernandes, em sua obra As técnicas de Reprodução Humana Assistida e a Necessidade de sua Regulamentação

${ }^{157}$ A íntegra deste projeto encontra-se no Anexo V a esta obra. 
Jurídica $^{158}$, propõe algumas sugestões de lege ferenda para uma legislação que discipline a utilização de técnicas de reprodução humana assistida.

Dentre as diversas sugestões, a autora expõe a necessidade de uma declaração escrita do doador sobre a utilização do sêmen, bem como a previsão de sua destruição em caso de morte do mesmo; a restrição da utilização da fecundação in vitro a fim de que não se criem embriões excedentes; somente se admitiria o congelamento de embriões quando a transferência não pudesse ocorrer logo após a concepção; limitação do número de óvulos colhidos para proceder à fecundação a 3 ou 4; etc.

As propostas trazidas pela autora fariam reduzir as possibilidades de concepção e implantação póstumas, uma vez que, com relação ao sêmen, no caso de morte do doador este deveria ser destruído e com relação aos embriões excedentários, estes não existiriam mais.

158 FERNANDES, Silvia da Cunha. As Técnicas de Reprodução Humana Assistida e a Necessidade de sua Regulamentação Jurídica. Rio de Janeiro: Renovar, 2005. p. 179. 


\section{CONCLUSÃo}

As técnicas de congelamento de sêmen e de embriões são largamente utilizadas na prevenção da fertilidade de homens e mulheres que irão se submeter a tratamento de doenças. A terapêutica nestes casos pode levar à esterilidade pelos efeitos indiretos da quimioterapia ou da radioterapia.

Ocorre que, após o falecimento do parceiro, a viúva, por razões diversas, expõe o desejo de ter prole do falecido esposo. Nesta situação abre-se um leque de questionamentos éticos e jurídicos:

Está justificado porque busca gerar vida? Se era desejo do casal ter filhos e se o procedimento é "pró-vida" parece aceitável. Porém, estando a criança fadada a nascer órfã de pai, isto feriria o princípio do melhor interesse da criança? Outro aspecto a ser discutido é a real motivação da mãe em gerar esta criança. Esta pode ser tanto para preenchimento do espaço deixado pelo ente falecido como também por motivos financeiros relacionados à herança e neste caso a criança está sendo um meio e não um fim, o que fere a dignidade da pessoa humana.

O direito da viúva sobre o sêmen de seu parceiro ou sobre os embriões do casal: se a questão foi previamente acordada entre as partes, a viúva tem direito a devolução do sêmen ou dos embriões. Todavia, a viúva não pode compelir a clínica a realizar o procedimento de concepção ou de fecundação embrionária sem a expressa autorização de seu cônjuge ou parceiro.

E a herança: sendo a criança concebida ou o embrião implantado após a morte do pai e após a partilha de bens, surgem sérios problemas de ordem sucessória.

O Conselho Federal de Medicina do Brasil não aborda a concepção e a implantação post mortem na resolução de Normas Éticas. Porém, desde que permite a inseminação de mulheres solteiras através de sêmen de 
doador, não parece, para nós, ilícito o uso do sêmen do esposo falecido ou a implantação embrionária post mortem, desde que haja expressa autorização do cônjuge ou companheiro.

A nosso ver, em se tratando de criança concebida in vitro e cujo pai faleceu antes da implantação do embrião, a criança herdaria de seu pai porque já concebida na data da abertura da sucessão. No caso de criança concebida, a máxima "infans conceptus pro nato habetur quoties de commodis ejus agitur” confere a aptidão a herdar sob a condição de nascer com vida.

Por outro lado, quanto à criança gerada por concepção post mortem, ou seja, gerada depois do falecimento do genitor biológico, pela utilização de sêmen congelado, é situação anômala, quer no plano do estabelecimento da filiação, quer no direito das sucessões. Nesta hipótese, em tese, a criança não herdaria de seu pai porque não estava concebida no momento da abertura da sucessão.

Mas se faz necessária solução favorável à criança e seus direitos devem ser garantidos por interpretação dos fundamentos constitucionais. Faz-se necessária, desta forma, disposição legislativa favorecendo o fruto de concepção post mortem. Sem esta previsão há que se cogitar a possibilidade de eventuais direitos sucessórios por meio de analogia legislativa e interpretação à luz da Constituição Federal. ${ }^{159}$ Não se deve, em detrimento dos direitos desta criança fruto de concepção post mortem, primar pela segurança jurídica.

O melhor interesse da criança e o princípio da dignidade da pessoa humana devem prevalecer quando se discute os direitos de uma criança, seja seu direito ao reconhecimento da paternidade, seja seu direito de herdar de seu pai, mesmo que este esteja morto antes de sua concepção.

\footnotetext{
159 LEITE, Eduardo de Oliveira. Comentários ao Novo Código civil. v. XX: do direito das sucessões. 4ª Ed. Rio de Janeiro: Forense, 2004. p. 109.
} 
A possibilidade de aproveitamento do material depositado para uso depois da morte do doador, como já vimos, é um assunto controvertido em diversos ordenamentos jurídicos e é procedimento vedado nas legislações alemã, sueca, francesa, etc. ${ }^{160}$

A concepção post mortem e a implantação de embriões post mortem são, portanto, procedimentos não regulamentados em nossa legislação, constitucional ou infraconstitucional. E, como já exposto, para que tais procedimentos sejam possíveis, é necessário o consentimento expresso do autor da herança, do de cujus, manifestado em vida, através de documento escrito ou por testamento, e por outro lado é necessário que o cônjuge ou companheiro sobrevivente continue na condição de viúvo ou não tenha constituído uma outra união estável, a fim de evitar a confusão de paternidade.

Mesmo sem o consentimento, caso seja realizada a concepção post mortem envolvendo um casal casado, surge a presunção de paternidade prevista no artigo 1.597, inciso III, do Código Civil. No caso de realizada a implantação embrionária post mortem, surge a presunção de paternidade prevista no artigo 1.597, inciso IV, do Código Civil. (E ambos os regramentos devem ser aplicados à união estável, desde que devidamente demonstrada a sua existência e não havendo litígio sobre a materialização da referida entidade familiar).

Desta forma, a criança assim concebida e gerada tem iguais direitos de família em comparação com os herdeiros da mesma classe e do mesmo grau, ou seja, é filha do falecido e do cônjuge ou companheiro sobrevivente, em atenção ao princípio constitucional da igualdade de filiação, previsto no artigo 227, § $6^{\circ}$, da Constituição Federal, corroborado pelo artigo 1.596, do Código Civil. 160 GIORGIS, José Carlos Teixeira. A inseminação Póstuma. Disponível em
<www.espacovital.com.br>. Acesso em 22 jun. 2008 . 
Com relação ao direito das sucessões, a interpretação da vocação hereditária, regulamentada pelo artigo 1.798, do Código Civil, deve observar que o legislador não previu a possibilidade de que uma pessoa falecida pudesse gerar um filho, através da utilização do seu material genético congelado, de maneira que, não havendo expressa vedação legal, deve o operador do direito compatibilizar essas novas possibilidades com os princípios constitucionais da igualdade da filiação e da liberdade do planejamento familiar, previstos no artigo $227, \S 6^{\circ}$, corroborado pelo artigo 1.596 do Código Civil e no artigo 226, § $7^{\circ}$, da Constituição Federal, bem como, com os princípios da dignidade da pessoa humana e do melhor interesse da criança, previstos respectivamente pelo artigo $1^{\circ}$, inciso III, e pelo artigo 227, caput, da Constituição Federal, corroborado pelos artigos $4^{\circ}$ e $6^{\circ}$ da Lei n. 8.069 de 1990, Estatuto da Criança e do Adolescente e pelo artigo 3.1 da Convenção Internacional dos Direitos da Criança, da ONU.

Defendemos que, com o objetivo de não se permitir que se prolongue indefinidamente a perspectiva da implantação embrionária post mortem e da fecundação post mortem, para que não ocasione insegurança no mundo jurídico, deverá o genitor morto ter estabelecido em vida, por documento escrito ou através de testamento, prazo não maior do que dois anos para realização do procedimento e concepção de sua prole eventual. Caso contrário, há de se aplicar, por analogia, o prazo máximo de dois anos, previsto para concepção da prole eventual de terceiro, beneficiada na sucessão testamentária, de acordo com o artigo 1.799, inciso I, combinado com o artigo $1.800, \S 4^{\circ}$, do Código Civil.

Assim, a possibilidade de não se reconhecer direitos à criança fruto do procedimento de implantação embrionária post mortem é inconcebível, a nosso ver, uma vez que, para fins sucessórios, a criança já estava concebida no momento da morte de seu genitor. E, paralelamente, a possibilidade de não se reconhecer direitos à criança gerada mediante concepção post mortem pune, em última análise, o afeto, a intenção de ter um filho com a pessoa amada, embora eventualmente afastada do convívio terreno. E, em 
ambos os casos, não é a falta de expressa autorização do genitor que vai impedir o reconhecimento de direitos.

Assim defende Albuquerque Filho:

"Pune-se o desejo de ter um filho, de realizar um sonho. Pune-se o amor que transpõe barreiras temporais, o amor perene, o amor verdadeiro, a fim de se privilegiar supostos direitos - patrimoniais - dos demais herdeiros. Tal perspectiva vai de encontro aos modernos princípios do direito de família, especialmente aos princípios da igualdade de filiação, da afetividade e da dignidade da pessoa humana." 161

Em conclusão, com relação ao procedimento de implantação embrionária post mortem, a criança já está concebida ao momento da morte de seu genitor. Portanto, já tendo havido a concepção, o embrião já tem vocação hereditária e direito à filiação conforme os artigos 1.798 e 1.597, inciso IV, do Código Civil.

A questão mais polêmica, contudo, se dá em definir a qualificação jurídica do concebido e nascido, mediante procedimento de reprodução assistida, ocorrida após a morte do titular da sucessão. Quanto à criança concebida por técnica reprodutiva post mortem, ou seja, criança gerada depois do falecimento do genitor biológico, pela utilização de sêmen congelado, é situação anômala, como já vimos, quer no plano do estabelecimento da filiação, quer no do direito das sucessões. E não podemos compartilhar da idéia de que, nesta hipótese, a criança não herdará de seu pai porque não estava concebida no momento da abertura da sucessão. E solução favorável à criança ocorreria, certamente, se houvesse disposição legislativa favorecendo o fruto de concepção post mortem. ${ }^{162}$

\footnotetext{
${ }^{161}$ FILHO, Carlos Cavalcanti de Albuquerque. Fecundação Artificial post mortem e o Direito Sucessório. In: PEREIRA, Rodrigo da Cunha. Anais do V Congresso de direito de Família. Disponível em <www.ibdfam.com.br>. Acesso em 13 mar. 2008.

162 LEITE, Eduardo de Oliveira. Comentários ao Novo Código civil. v. XX: do direito das sucessões. $4^{\mathrm{a}}$ Ed. Rio de Janeiro: Forense, 2004. p.110
} 
Como opina Carlos Cavalcanti de Albuquerque Filho ${ }^{163}$, não se pode excluir da participação nos efeitos jurídicos, no meio do direito de família e no direito das sucessões, a criança gerada por intervenção médica ocorrida após a morte do autor da sucessão, sob a justificativa de que a sua inclusão prejudicaria o direito de outros herdeiros já existentes. Também não se deve suscitar o princípio da segurança jurídica para excluir a criança concebida post mortem da sucessão de seu genitor, uma vez que a própria possibilidade jurídica da utilização de petição de herança, nos termos do artigo 1.824 , do Código Civil ${ }^{164}$, demonstra desde $\operatorname{logo}$ a insegurança relativa de qualquer sucessão.

Portanto, diante de tais questões, ou seja, diante de uma criança fruto de implantação embrionária post mortem ou de concepção post mortem, não se deve discutir se o autor da herança desejou ter o filho, e nem mesmo se deixou autorização expressa, pois o simples fato de a criança existir e uma vez comprovada a relação de parentesco, nos termos do artigo 1.597, do Código Civil, já é suficiente para essa criança ser herdeira legítima, com direito à sucessão.

Ou seja, o filho gerado por implantação embrionária post mortem sem dúvida alguma tem seus direitos hereditários e de filiação garantidos por lei. Já o filho gerado através de concepção post mortem terá direito de ser reconhecido, por meio de analogia e interpretação jurídica, com base nos princípios da dignidade da pessoa humana, do melhor interesse da criança e da igualdade entre os filhos.

É importante esclarecer, nesta conclusão, que não compartilhamos da opinião de serem essas práticas estimuladas. Entendemos que, para que

\footnotetext{
${ }^{163}$ FILHO, Carlos Cavalcanti de Albuquerque. Fecundação Artificial post mortem e o Direito Sucessório. In: PEREIRA, Rodrigo da Cunha. Anais do V Congresso de direito de Família. Disponível em <www.ibdfam.com.br>. Acesso em 13 mar. 2008.

164 Art. 1.824. O herdeiro pode, em ação de petição de herança, demandar o reconhecimento de seu direito sucessório, para obter a restituição da herança, ou de parte dela, contra quem, na qualidade de herdeiro, ou mesmo sem título, a possua.
} 
sejam possíveis, deve haver expressa autorização do cônjuge ou companheiro já falecido. No entanto, independentemente disso, o simples fato de a criança fruto de concepção ou implantação embrionária póstumas existir, tendo havido ou não expressa autorização, já é suficiente para que tenha sua paternidade reconhecida e para que seja herdeira legítima, com direito à sucessão de seu pai, com base na legislação em vigor e na interpretação constitucional. 


\section{BiblografiA}

AGUIAR, Mônica. Direito à filiação e bioética. Rio de Janeiro: Forense, 2005 .

ALMEIDA, José Luiz Gavião de. Código civil comentado: Direitos das Sucessões. Sucessão em geral. Sucessão legítima - Artigos 1.784 a 1.856 v. XVIII. São Paulo: Atlas, 2003.

AMARAL, Francisco. A Visão do Biodireito. In: Anais do Encontro Regional do Simpósio de Bioética e Biodireito, 1997.

BARBOZA, Heloisa Helena. Princípios do Biodireito. In: Novos Temas de Biodireito e Bioética. Org. Heloisa Helena Barboza et al. Rio de Janeiro: Renovar, 2005.

Id., O princípio do melhor interesse da criança e do adolescente. In: Anais do XX Congresso de Direito de Família. Disponível em $<w w w . i b d f a m . c o m . b r>$. Acesso em 8 set. 2008.

Id., O Estatuto da Criança e do Adolescente e a disciplina da filiação no Código Civil. In: $O$ melhor interesse da criança: um debate interdisciplinar. Rio de Janeiro: Renovar, 1999.

BITTAR, Carlos Alberto. O direito de família e a Constituição de 1988. In: O nascituro no Código Civil e no nosso direito constituendo. São Paulo: Saraiva, 1989.

COULANGES, Fustel de. A Cidade Antiga. $4^{\mathrm{a}}$ Ed. Martins Fontes. São Paulo, 2000. 
DIAS, Maria Berenice. Manual das Sucessões. São Paulo: Revista dos Tribunais, 2008.

Id., Manual de Direito das Famílias. $4^{\mathrm{a}}$ Ed. São Paulo: Revista dos Tribunais, 2007.

DINIZ, Maria Helena. O Estado Atual do Biodireito. São Paulo: Saraiva, 2007.

FACHIN, Luiz Edson. Da Paternidade: relação biológica e afetiva. Disponível em <www.ibdfam.com.br>. Acesso em 13 mai. 2008.

FERNANDES, Silvia da Cunha. As Técnicas de Reprodução Humana Assistida e a Necessidade de sua Regulamentação Jurídica. Rio de Janeiro: Renovar, 2005.

FERREIRA, Jussara Suzi Assis Borges Nasser. Bioética e Biodireito. Disponível em <www.uel.br/cesa/dir/pos/publicacoes/pubjussaraf.html.>. Acesso em 18 jul. 2008.

FILHO, Carlos Cavalcanti de Albuquerque. Fecundação Artificial post mortem e o direito Sucessório. In: PEREIRA, Rodrigo da Cunha. Anais do $V$ Congresso de Direito de Família. Disponível em <www.ibdfam.com.br>. Acesso em 13 mar. 2008.

FRASÃO, Alexandre Gonçalves. A fertilização "in vitro": uma nova problemática jurídica. Disponível em <www.jus.com.br>. Acesso em 20 set. 2008. 
GAMA, Guilherme Calmon Nogueira da. A nova filiação: o biodireito e as relações parentais. Rio de Janeiro: Renovar, 2003.

GEBLER. Le droit français de filiation et la verité. th. L.G.D.J., 1970.

GIORGIS, José Carlos Teixeira. A inseminação Póstuma. Disponível em <www.espacovital.com.br>. Acesso em 22 jun. 2008.

Id,. A implantação de embriões e a recusa do marido. Disponível em <www.ibdfam.com.br>. Acesso em 22 jun. 2008.

GOZZO, Débora. VENOSA, Silvio de Salvo. Comentários ao Código Civil Brasileiro. Vol. XVI. Rio de Janeiro: Forense, 2004.

HIRONAKA Giselda Maria Fernandes Novaes. Comentários ao Código Civil - Parte especial: do direito das sucessões. v. XX. $2^{\mathrm{a}}$ ed. São Paulo: Saraiva, 2003.

Id., Direito das Sucessões. $3^{\mathrm{a}}$ Ed. Rio de Janeiro: Revista dos Tribunais, 2007.

Id., As inovações biotecnológicas e o direito das sucessões. Disponível em <www.ibdfam.com.br>. Acesso em 10 jul. 2008.

Id., Reprodução assistida após a morte e o direito de herança. Disponível em <www.ibdfam.com.br>. Acesso em 23 jun. 2008.

JUNIOR, Jesualdo Eduardo de Almeida. Técnicas de reprodução assistida e o biodireito. Disponível em <http://www.jusnavigandi.com.br>. Acesso em 10 jul. 2008. 
KANT, Immanuel. Fundamentação da metafísica dos costumes. São Paulo: Martin Claret, 1990.

LEITE, Eduardo de Oliveira. Procriações artificiais e o direito: aspectos médicos, religiosos, psicológicos e jurídicos. São Paulo: Revista dos Tribunais, 1995.

Id., Bioética e Presunção de paternidade (considerações em torno do art. 1.597 do Código Civil.) In: Grandes temas da atualidade: Bioética e Biodireito, coord. Eduardo de Oliveira Leite. $1^{\text {a }}$ Ed. Rio de Janeiro: Forense, 2004.

Id., Comentários ao Novo Código Civil. Vol. XX: do direito das sucessões. $4^{\mathrm{a}}$ Ed. Rio de Janeiro: Forense, 2004.

LOBO Paulo Luiz Netto. Entidades familiares constitucionalizadas: para além do numerus clausus. In: Anais do III Congresso Brasileiro de Direito de Família. Família e cidadania. Coord. Rodrigo da Cunha Pereira. Disponível em <www.ibdfam.com.br>. Acesso em 20 mai. 2008.

Id., Código Civil Comentado: direito de família. Relações de parentesco. Direito patrimonial. v. XVI. Artigos 1.591 a 1.693. Coord. Álvaro Vilaça Azevedo. São Paulo: Atlas, 2003.

Id., Direito ao Estado de Filiação e Direito à Origem Genética: uma distinção necessária. Disponível em <www.ibdfam.com.br>. Acesso em 27 set. 2008.

MEIRELLES, Jussara Maria Leal de. Os Embriões Humanos Mantidos em Laboratório e a proteção da pessoa: o novo Código Civil Brasileiro e o 
texto Constitucional. In: Novos temas de Biodireito e Bioética. Coord. Heloisa Helena Barbosa et al. Rio de Janeiro: Renovar, 2000.

MORAES, Maria Celina Bodin de. Danos à Pessoa Humana: uma leitura civil-constitucional dos danos morais. Rio de Janeiro: Renovar, 2003.

NETTO, Roberta de Freitas. Uma nova lei: uma guarda planejada em prol do melhor interesse da criança e do adolescente. Disponível em <www.ibdfam.com.br>. Acesso em 26 set. 2008.

NEVARES, Ana Luiza Maia. O Princípio da Intangibilidade da Legítima. Princípios do Direito Civil Contemporâneo. In: Danos à Pessoa Humana: uma leitura civil-constitucional dos danos morais. Coord. Maria Celina Bodin de Moraes. Rio de Janeiro: Renovar, 2003.

PÁDUA, Amélia do Rosário Motta de. Responsabilidade Civil na Reprodução Assistida. Rio de Janeiro: Lúmen Júris, 2008.

PEREIRA, Caio Mário da Silva. Instituições de Direito Civil. Vol. VI. 16 Ed. Rio de Janeiro: Forense, 2007.

Id., Instituições de Direito Civil. Vol. V. 16 ${ }^{\mathrm{a}}$ Ed. Rio de Janeiro: Forense, 2006.

PEREIRA. Rodrigo da Cunha. Apresentação ao II Congresso Brasileiro de Direito de Família. In: Anais do II Congresso Brasileiro de Direito de Família. Disponível em <www.ibdfam.com.br>. Acesso em 15 jun. 2008.

PETRACCO, Álvaro et al.. Bioética e Reprodução Assistida. In: Grandes temas da atualidade: Bioética e Biodireito, coord. Eduardo de Oliveira Leite. $1^{\text {a }}$ Ed. Rio de Janeiro: Forense, 2004. 
QUEIROZ, Juliane Fernandes. Paternidade: aspectos jurídicos e técnicas de inseminação artificial. Belo Horizonte: Del Rey, 2001.

REALE, Miguel. História do Novo Código Civil - Col. Biblioteca de Direito Civil - Vol. 1. São Paulo: Revista dos Tribunais, 2005.

RODRIGUES, Silvio. Direito Civil, v. 7. Direito das sucessões. 26 ${ }^{\mathrm{a}}$ Ed. São Paulo: Saraiva, 2006.

PÁGINAS DA INTERNET:

http://pt.wikipedia.org/wiki/Biotecnologia

http://www.brasilescola.com/biologia/biotecnologia.htm

http://www.espacovital.com.br

http://www.ghente.org/temas/reproducao/index.htm

http://www.ibdfam.org.br

http://www.stf.gov.br

http://www.tj.rj.gov.br

http://www1.folha.uol.com.br/folha/ciencia/ult306u406822.shtml 


\section{ANEXO I}

RESOLUÇÃO CFM No 1.358, DE 1992

O CONSELHO FEDERAL DE MEDICINA, no uso das atribuições que lhe confere a Lei $\mathrm{n}^{\mathrm{o}} 3.268$, de 30 de setembro de 1957, regulamentada pelo Decreto 44.045, de 19 de julho de 1958, e

CONSIDERANDO a importância da infertilidade humana como um problema de saúde, com implicações médicas e psicológicas, e a legitimidade do anseio de superá-la;

CONSIDERANDO que o avanço do conhecimento científico já permite solucionar vários dos casos de infertilidade humana;

CONSIDERANDO que as técnicas de Reprodução Assistida têm possibilitado a procriação em diversas circunstâncias em que isto não era possível pelos procedimentos tradicionais;

CONSIDERANDO a necessidade de harmonizar o uso destas técnicas com os princípios da ética médica;

CONSIDERANDO, finalmente, o que ficou decidido na Sessão Plenária do Conselho Federal de Medicina realizada em 11 de novembro de 1992;

\section{RESOLVE}

Art. $1^{\circ}$ - Adotar as NORMAS ÉTICAS PARA A UTILIZAÇÃO DAS TÉCNICAS DE REPRODUÇÃO ASSISTIDA, anexas à presente Resolução, como dispositivo deontológico a ser seguido pelos médicos.

Art. $2^{\circ}$ - Esta Resolução entra em vigor na data da sua publicação.

\section{NORMAS ÉTICAS PARA A UTILIZAÇÃO DAS TÉCNICAS DE REPRODUÇÃO ASSISTIDA}

\section{I - PRINCÍPIOS GERAIS}

1 - As técnicas de Reprodução Assistida (RA) têm o papel de auxiliar na resolução dos problemas de infertilidade humana, facilitando o processo de procriação quando outras terapêuticas tenham sido ineficazes ou ineficientes para a solução da situação atual de infertilidade. 